\title{
Türkiye’nin Avrupa Birliği Çevre Politikalarına Uyum Sürecinin Değerlendirilmesi
}

\author{
Mehmet Samet ERDEM* ${ }^{*}$ Füsun YENILMEZ** \\ ÖZ
}

1970'li yıllarda Roma Kulübü tarafından başlatılan çevre konusundaki farkındalık, AB'de sürekli olarak gelişen bir sürecin başlangıç noktasını oluşturmuştur. Sonraki süreçte çevreyle ilgili alınması gereken önlemler ve uygulanması düşünülen politikalar, anlaşmalar, strateji belgeleri ve Çevre Eylem Programları kapsamında somutlaştırılmıştır.

Türkiye, çevre konusunu öncelikle kalkınma planları çerçevesinde ele almıştır. Kalkınma planlarının gelişme sürecinde, Türk çevre politikalarının $\mathrm{AB}$ politikalarına uyumu çalışmanın ana konusunu oluşturmaktadır. $\mathrm{Bu}$ çerçevede ilk olarak Türkiye ve $\mathrm{AB}$ mevzuat olarak karşılaştırılmıştır. Daha sonra ekonomik açıdan kamu ve özel sektörün çevresel koruma, harcamalar ve yatırımları da karşılaştııılmış ve bu doğrultuda Türkiye'nin çevre politikalarına uyum sürecindeki son durumu değerlendirilmiştir. Buna göre Türkiye'nin AB'ye çevre politikaları açısından uyumu için daha ulaşılabilir politikalar belirlemesi ve hayata geçirmesi gerektiği sonucuna varılmıştır.

Anahtar Kelimeler: Avrupa Birliği, Türkiye, Çevre Politikası, Kalkınma Planı, Çevre Eylem Programı

JEL Sınıflandırması: Q56, O13, N50

\section{Assessment of Turkey's Harmonization Process to the European Union Environmental Policies}

\begin{abstract}
In the 1970s, awareness of the environment initiated by the Club of Rome has been the starting point of a continuous process developing within the EU. In the next process, the measures to be taken and considered policies to be implemented about environment are objectified by in the framework of agreements, strategy papers and Environment Action Programmes.

Turkey, primarily approaches environmental issues within the framework of development plans. In the development process of development plans, the adaptation of Turkish environmental policies to the EU policies is the main purpose of the study. In this context, firstly Turkey and EU was compared in terms of legislations. Then the public and private sector's environmental protection expenditures and investments was compared in terms of economy, and in this sense, Turkey's recent situation in adaptation process to environmental policies have been assessed. Accordingly, it is concluded that Turkey needs to determine and adopt more accessible policies to be harmonized with the EU in terms of environmental policies.
\end{abstract}

Keywords: EU, Turkey, Environment Policy, Development Plan, Environment Action Programme

JEL Classification: Q56, O13, N50

Geliş Tarihi / Received: 17.02.2017 Kabul Tarihi / Accepted: 27.03.2017

\footnotetext{
*Uzman, Sinop Üniversitesi, mehmetsameterdem@ hotmail.com

** Doç.Dr., Eskişehir Osmangazi Üniversitesi, İ̈BF, İktisat Bölümü, yenilmez@ogu.edu.tr
} 


\section{GíRiş}

Günümüzden yaklaşık 10 bin y1l önce başlayan insanın doğal çevre ile olan ilişkisi, 18.yy dan itibaren sanayi devrimiyle birlikte değişime uğramış artan tüketim, üretim, nüfus ve ekonomik faaliyetlerin hacmiyle kontrolsüz bir tahribata dönüşmüştür. Bilgi toplumuna geçtiğimiz bu günlerde insan-çevre ilişkisi yeni bir döneme girerek planlı ve çevre duyarlılığ 1 yüksek politikalar benimsenmeye başlanmıştır (Dağdemir, 2015:1).

$\mathrm{Bu}$ farkındalık, bireysel düzeyde başlayarak artan bir şekilde ülkelerin ve birliklerin politikalarında da yer etmeye başlamıştır. Dahası bu politikalar ülkelerin birbirleriyle olan ilişkilerinde etkili olmuş, bireylerin tüketim alışkanlıkları bu çerçevede değerlendirilerek üretimin de bu politikalara ayak uydurması beklenmiştir. Çevre politikaları olarak ifade edilen bu politikalar zamanla gelişerek üretimin ve tüketimin yaşanabilir bir çevreyi tahrip etmesinin sınırlarını çizmeye çalışmıştır.

Çevre politikası, çevre sorunlarının çözümü için geleceğe yönelik olarak alınması gereken tedbirlerin ve benimsenen ilkelerin bütününü oluştururken, bir ülkenin çevre konusundaki tercih ve hedeflerinin belirlenmesi olarak da tanımlanabilir (Bayram vd, 2011: 34).

Avrupa Birliği’nin çevre politikasına bakıldığında; kirliliği kaldırmayı, azaltmayı ve önlemeyi, sürdürülebilir kalkınmayı sağlarken doğal kaynakların, ekolojik dengeye zarar vermeyecek biçimde kullanılmasının temin edilmesini, çevresel zararın kaynağında önlenmesini ve çevreyi korumanın diğer sektörel politikalarla (enerji, ulaştırma v.b.) entegrasyonunu güvence altına almayı hedeflediği görülmektedir (AB, 2016: 1).

Türkiye'nin çevre politikası ise 1970'li yıllardan başlayarak günümüze kadar sürekli değişen bir trend sergilemiştir. Çalışmada Türkiye'nin çevresel öncelikleri, kalkınma hedefinin gerisinde görmesi ya da öteleme zorunluluğu göz önünde bulundurularak bu değişim trendinin geçtiği aşamalar kalkınma planları çerçevesinde ele alınmaya çalışılmıştır.

Çalışmanın ilk bölümünde $\mathrm{AB}$ çevre politikalarının tarihsel gelişimi 1945 -1970 dönemi ve 1970 sonrası dönem olarak iki bölümde ele alınmaktadır. Bu ayrımın amacı çevre politikalarının gerek AB gerekse Türkiye'de 1970 yılı sonrasında yaşadığı dönüşümdür. Bu çalışmada Avrupa'nın Birliğe giden yolda yaptığı anlaşmalar incelenerek çevreyi ilgilendiren bölümler ele alınmış, bunun yanı sıra Çevre Eylem Programları incelenerek çevre politikasını oluşturan evreler ve bu politikaların son biçimi belirtilmeye çalışılmıştır.

Çalışmanın ikinci bölümünde Türkiye'nin çevre politikalarının tarihsel gelişimi planlı döneme geçişle birlikte başlayan kalkınma planları çerçevesinde ele alınmaktadır. İnceleme yapılırken AB'nin geçirdiği süreçlerle olan uyumu her kalkınma planı döneminde ayrı ayrı değerlendirilmeye çalışılmıştır. Böylelikle Türkiye özelinde inceleme yapılırken bir yandan da bir önceki bölümde ifade edilen $\mathrm{AB}$ çevre politikalarının uyumu ortaya konmaya çalışılacaktır.

Çalışmanın son bölümü çevre politikalarının ekonomik göstergeler çerçevesinde değerlendirilmesinden oluşmaktadır. Bu bölümde Türkiye, $\mathrm{AB}$ 'nin kurucu ülkelerinden üç tanesi olan Fransa, Almanya, Belçika ve Birliğe son katılan üç ülke Hirvatistan, Bulgaristan ve Romanya ile kamu ve özel sektörün çevresel koruma harcama ve yatırımları açısından karşılaştırılmaya çalışılacaktır.

\section{LITERATÜR TARAMASI}

Ülkelerin öncelikleri arasında önemli ölçüde yer tutmaya başlayan çevre politikaları, akademisyenlerin çevrenin politik, ekonomik ve sosyal çerçevesini bilimsel olarak incelemesinin önemini arttırmıştır. Literatürde konuyla ilgili çalışmalar yapılarak gerek ülke politikaları 
gerekse bu ülke politikalarının diğer ülke ya da birliklerle olan ilişkisi ortaya konmaya çalışılmıştır. Bu çalışmaların özet literatürü Tablo 1'de verilmiştir.

Tablo 1: Türkiye ve Avrupa Birliği Çevre Politikalarının Karşılaştırmalı Analizini İçeren Literatür Özeti

\begin{tabular}{|c|c|c|c|}
\hline Yll & Yazar(lar) & Yöntem & Sonuç \\
\hline 2005 & Yildiz & Karşılaştırmalı Analiz & $\begin{array}{l}\text { Türkiye'nin AB'nin çevre } \\
\text { politikasına uyum yolunda } \\
\text { önemli ilerlemeler } \\
\text { kaydettiğini ancak genel } \\
\text { olarak çevre } \\
\text { müktesebatının } \\
\text { aktarılmasında yeterli } \\
\text { seviyeye gelemediğini } \\
\text { ifade etmiştir. Hava } \\
\text { kalitesi, atı yönetimi, su } \\
\text { kalitesi, doğanın korunması } \\
\text { ve endüstriyel kirlilik gibi } \\
\text { konuların üzerinde } \\
\text { özellikle durulması } \\
\text { gerektiği belirtmiştir. }\end{array}$ \\
\hline 2006 & Toprak & Karşılaştırmalı Analiz & $\begin{array}{l}\text { AB çevre politikası } \\
\text { alanında ekonomik ve mali } \\
\text { araçların kullanımında } \\
\text { Türkiye'nin yol almasına } \\
\text { karşılık sınırlı kaldığını, bu } \\
\text { çerçevede alınan vergilerin } \\
\text { çevreyi koruma önceliğinde } \\
\text { kullanılmamasının } \\
\text { yeterince yol } \\
\text { alınamamasında etkili } \\
\text { olduğunu belirtmiştir. }\end{array}$ \\
\hline 2007 & Çokgezen & Karşılaştırmalı Analiz & $\begin{array}{l}\text { AB'nin çevre konusundaki } \\
\text { şartlarının Türkiye'de } \\
\text { başarılı olarak } \\
\text { uygulanabilmesinin sadece } \\
\text { mevzuatla olamayacağını } \\
\text { bunun yanında güçlü bir } \\
\text { kurumsal idari kapasitenin, } \\
\text { yerel otoritenin ve alt } \\
\text { yapının gerekli olduğunu } \\
\text { belirtmiştir. }\end{array}$ \\
\hline 2007 & Duru & Karşılaştırmalı Analiz & $\begin{array}{l}\text { Türkiye'nin AB'ye uyum } \\
\text { sürecinde karşılaştığı } \\
\text { sorunun yasal } \\
\text { düzenlemeleri } \\
\text { gerçekleştirmede değil } \\
\text { yasaları yaşama geçirmede, } \\
\text { çevre politikalarını diğer } \\
\text { politikalarla } \\
\text { uyumlaştırmada ve } \\
\text { kurumsal kapasiteyi } \\
\text { güçlendirmede ortaya } \\
\text { çıtığını belirtmiştir. }\end{array}$ \\
\hline 2010 & Yıldırım ve Budak & Karşılaştırmalı Analiz & $\begin{array}{l}\text { Türkiye'nin çevre } \\
\text { politikalarının AB'ye göre } \\
\text { yetersiz olduğunu, bu } \\
\text { durumun bazı sorunlar }\end{array}$ \\
\hline
\end{tabular}




\begin{tabular}{|c|c|c|c|}
\hline & & & $\begin{array}{l}\text { doğuracağını, çevre için } \\
\text { yapılacak yatırımlarda } \\
\text { önemli miktarda ekonomik } \\
\text { ve mali kaynağa ihtiyaç } \\
\text { olduğunu, buna rağmen } \\
\text { Türkiye'nin bu değişimin } \\
\text { üstesinden gelebileceğini } \\
\text { belirtmişlerdir. }\end{array}$ \\
\hline 2011 & Bayram vd. & Karşılaştırmalı Analiz & $\begin{array}{l}\text { Yerel idarelerin önemine } \\
\text { değinerek uygulanacak } \\
\text { politikalar için kaynak } \\
\text { ihtiyacı olduğunu ifade } \\
\text { etmişlerdir. Fon } \\
\text { kaynaklarına ulaşılabilmesi } \\
\text { için proje hazırlama ve } \\
\text { uygulama konularına önem } \\
\text { verilmesi gerektiğini } \\
\text { böylelikle hibe } \\
\text { programlarıyla hem } \\
\text { ekonomik kalkınmaya hem } \\
\text { de çevre politikalarının } \\
\text { uygulanmasına destek } \\
\text { olunacağını belirtmişlerdir. }\end{array}$ \\
\hline 2013 & Şeren ve Dedebek & Karşılaştırmalı Analiz & $\begin{array}{l}\text { AB'ye katılım şartlarının } \\
\text { ve serbest piyasa } \\
\text { ekonomisinin arasında } \\
\text { kalan Türkiye'nin tutarlı } \\
\text { politikalar } \\
\text { oluşturamadığına işaret } \\
\text { etmiştir. Bu bağlamda } \\
\text { oluşturulacak politikaların } \\
\text { kendi dinamiklerine uygun } \\
\text { olarak şekillendirilmesi } \\
\text { gerektiğini belirtmiştir. }\end{array}$ \\
\hline 2014 & Biyan ve Gök & Karşılaştırmalı Analiz & $\begin{array}{l}\text { Küresel düzeyde gelişen } \\
\text { çevre hassasiyetinin } \\
\text { Türkiye'de de arttı̆̆ını, bu } \\
\text { bağlamda çevreyi } \\
\text { korumaya yönelik bir vergi } \\
\text { sisteminin tasarlanması } \\
\text { gerekirken mevcut } \\
\text { vergilerin de yeniden } \\
\text { düzenlenmesi gerektiğini } \\
\text { belirtmişlerdir. Bu } \\
\text { düzenlemelerin çevrenin } \\
\text { korunmasının yanında } \\
\text { üyelik müzakerelerinde } \\
\text { bulunduğu AB'ye karş1 } \\
\text { yükümlülüklerini yerine } \\
\text { getirebilmesi açısından da } \\
\text { önemli olduğunu ifade } \\
\text { etmişlerdir. }\end{array}$ \\
\hline
\end{tabular}

Kaynak: Yazar tarafindan derlenmiştir.

\section{AB ÇEVRE POLITIKALARININ TARIHSEL GELIŞíi}

İkinci Dünya Savaşından sonra gerek dönemin şartları gerekse zorunluluk olarak ifade edilebilecek Birleşik Avrupa fikri, yıllar itibariyle gelişerek bugün bilinen 28 üyeli Avrupa 
Birliği şeklini almıştır. Bu gelişme sürecinde sadece ekonomik birlik sağlanmaya çalışılmamış aynı zamanda sosyal olarak da bir değişim süreci yaşanmıştır.

Birlik, bireylerin daha iyi bir çevrede yaşaması ve gelecek kuşaklara daha iyi bir çevre bırakılması için yıllar içerisinde gelişen önlemler alıp politikalar uygulamaya çalışmıştır. Çalışmanın bu bölümünde incelenecek olan bu önlemler ve politikalar İkinci Dünya Savaş1-1970 dönemi ve 1970 sonrası dönem olarak iki bölümde incelenecektir.

\subsubsection{5-1970 Dönemi}

Savaş sonrası Avrupa'daki yıkımın tamir edilebilmesi için birliğin sosyo-ekonomik altyapısı tam istihdam ve sosyal güvenlik devleti üzerine inşa edilmiş, IMF, GATT, Dünya Bankası gibi kurumlar ve Bretton Woods uluslararası para sistemi gibi enstrümanlarla savaş sonrasında uluslararası düzeyde liberal ilişkiler, ulusal düzeyde ise halka istikrarlı ve güvenli bir şekilde yaşamasını sağlayacak ekonomik tedbirlerin beraber yürütülmesi planlanmıştır (Erdoğdu, 2006: 213).

1948-1951 yıllarını kapsayan Marshall planının uygulanması ile hemen hemen aynı döneme denk gelen Avrupa Kömür ve Çelik Topluluğu(AKÇT)'nun kurulmasıyla birlikte üye ülkelerde hızlı bir kalkınma sürecine girilmiştir. Savaş sonrası devam eden 10 yıllık dönem savaşın yaralarının sarılmasına yönelik olarak Avrupa'nın ekonomik olarak gelişmesine ağırlık verildiği dönem olarak ifade edilebilir.

1957 yılına gelindiğinde Avrupa Ekonomik Topluluğu'nu kuran Roma Antlaşması imzalanarak yaşam ve çalışma koşullarının iyileşmesi ve bu konuda üye devletlerin arasındaki uyumu sağlamak amaçlanmıştır (Özgüler, 2013: 78-79). Altın Çağ olarak ifade edilen 1960'lı yıllarda ise eğitim, sağlık ve çalışma koşulları başta olmak üzere sosyal gelişmeye yönelik önemli adımların atıldığı görülmektedir.

1945 ile 1970'lerin ortalarına kadar AB ekonomik olarak büyüme, istikrar ve sosyal uyum üzerine kurulu bir yapıya sahip olurken, 1970'li yıllara gelindiğinde dünya genelinde yaşanan petrol şokları, bu zamana kadar yükselen refah düzeyi, sosyal politikalar, büyüme ve istihdam olgularında düşüş yaratarak bu konularla ilgili politikaların tekrar gözden geçirilmesine neden olmuştur.

Avrupa İç Pazarının gelişmesinden sonra, 1967 yılında tehlikeli kimyasalların sinıflandırılması ve etiketlenmesi ile ilgili direktif ile başlayan çevre koruma hedefleri ve ilkelerine, 1987 yılında AB'yi kuran anlaşmada kendi başına bir bölüm olarak yer verilmiştir. (Scheuer, 2005: 8).

\subsubsection{Sonrası Dönem}

1957-1972 yılları arasında Avrupa Ekonomik Topluluğu'nun çevre politikaları, bir dizi önemsiz önlem olarak tanımlanmaktadır. Avrupa Ekonomik Topluluğu'nun öncelik olarak ortak pazar ve ekonomik büyüme hedeflerine odaklanması 1958 Roma Antlaşmasında çevre ile ilgili belirgin hiçbir ibarenin olmamasının en büyük nedeni olarak ifade edilmektedir (Burchell ve Lightfoot, 2001: 34).

1970’li yıllarda Batı Avrupa'da ortaya çıkan, İtalyan Fiat otomobil grubunun üst düzey yöneticilerinden oluşan "Roma Kulübü” isimli bir grubun ekonomik büyümenin beraberinde getireceği çevre sorunlarına yönelik olarak ifade ettikleri endişelerin ve "Yeşiller" adı verilen bir başka grubun çevrenin aşırı tahrip edilmesinden duydukları endişelerin sonucu ortaya koydukları yeni politika talepleri çevre konusunda yeni duruşlar sergilenmesinin ilk adımlarını oluşturmuştur (Budak, 2000: 113-114). 
1971 y1lında Avrupa Topluluğu Komisyonu'nun çevre konusundaki ilk bildirisinde Konsey'e, Avrupa Ekonomik Topluluğu anlaşmasının 100. ve 235. maddelerini dayanak göstererek kapsamlı bir çevre koruma faaliyeti hazırlanması önerilmiştir. Bu bildiriye ek olarak 1972 yılında ikinci bir bildiri daha yayınlanmış ve bu iki bildiri 1972 yılında Paris’te yapılan Avrupa Zirvesi'nde alınan kararları etkilemiş̧ir (Budak, 2000: 114).

$\mathrm{Bu}$ yıllarda çevre konusundaki bir başka önemli konferans olan 1972 yılında Stockholm’de yapılan Birleşmiş Milletler İnsan Çevresi Konferansı, Avrupa Birliği çevre politikasının gelişiminde büyük bir dönüm noktası olarak kabul edilmektedir. Konferans sonrasında 1973 yılında Avrupa Çevre Politikası "Roma Kulübü" tarafindan yayınlanan "Büyümenin Sınırları" hakkında toplumun ve bilimin kaygılarına işaret ederek başlamıştır (Scheuer, 2005: 12).

Bütün bu gelişmelerle beraber, 1972 yılında Paris’te yapılan zirvede, Avrupa Topluluğu bünyesinde çevre politikaları ilk defa hükümetler düzeyinde ele alınmıştır. Bu kapsamda topluluk çevre politikasının belirlenebilmesi için çevre eylem planının hazırlanmasının ilk adımı atılmıştır. Bu zirvede topluluk çevre politikasının amacı, yaşanan çevrenin ve yaşam koşullarının kalitesinin yükseltilmesi olarak belirlenmiştir.

\subsubsection{Avrupa Tek Senedi}

1986 Y1lında imzalanan 1987 y1lında yürürlüğe giren Avrupa Tek Senedi ile beraber Avrupa Birliği tek pazarını ve Avrupa Politik İş Birliğini resmen başlatan Roma Antlaşması'nda köklü değişiklikler yapılmıştır. Bu köklü değişikliklerle beraber çevre politikası ile ilgili yeni bir süreç başlamıştır. Çevre adındaki VI. alt başlıkta AET anlaşmasının üçüncü kısmına bir VII. başl1k eklenmiştir. 130r, 130s ve 130t maddelerinden oluşan VII. çevre başlığı:

- Çevreyi muhafaza etme, koruma ve çevre politikasını yükseltme,

- Kişilerin sağlığının korunması için çalışma,

- Doğal kaynakların dikkatli ve rasyonel kullanımını sağlamayı amaçlamaktadır.

Topluluğun bu kapsamdaki çevre ile ilgili faaliyeti:

- Önleyici olarak harekete geçilmesi,

- Çevreye verilen zararların kaynağına öncelik verilerek, önlemler alınması,

- "Kirleten Öder" ilkeleri üzerine kurulmuştur (SEA, 1986: 17-18).

\subsubsection{Maastricht Antlaşması}

1992 tarihinde imzalanan ve 1993 tarihinde yürürlüğe giren Maastricht Antlaşması ile Avrupa Topluluğu, Avrupa Birliği adını alarak Avrupa Topluluklarına yeni boyutlar kazandırılmış ve yeni bir hukuksal yapı düzenlenmiştir. Çevre ile ilgili olarak AET anlaşmasının 130r, 130s ve 130t maddeleri bu kapsamda genişletilerek yeniden düzenlenmiştir. Buna göre Maastricht Antlaşması'nın XVI. çevre başlığında AET anlaşmasının VII. çevre başlığındaki amaçlara ek olarak bölgesel ya da küresel çevre sorunlarına karşı koymayı hedefleyen önlemlerin uluslararası düzeyde geliştirilmesi maddesi eklenmiştir (TEU, 1992: 58-60).

Maastricht Antlaşması'nda çevre ile ilgili olarak ifade edilmesi gereken bir diğer önemli husus çevre politikalarında sürdürülebilirlik ilkesinin ilk defa gündeme gelmesidir. Bu kapsamda Birliğin temel ilkelerinin yer aldığı 2.maddede, "Topluluğun bütünü içinde dengeli ekonomik kalkınma faaliyetlerinin sürdürülebilir, enflasyonist olmayan ve çevreye duyarlı bir büyümenin, ekonomik performansların yüksek derecede bütünlüğünün, yüksek seviyede istihdam ve sosyal 
korumanın, yaşam seviyesinin ve kalitesinin yükseltilmesinin” topluluğun görevi olduğu belirtilmiştir (TEU, 1992: 11).

\subsubsection{Amsterdam Antlaşması}

1997 y1lında Avrupa Birliği üyesi ülkelerce imzalanarak 1999 yılında yürürlüğe giren Amsterdam Anlaşması'nda daha önce belirlenmiş olan çevre politikaları üzerinde büyük değişiklikler yapılmasa da önemli görülen hususlara vurgu yapılmıştır. Böylece 1.Maddenin 2. bendinde çevrenin sürdürülebilir kalkınma çerçevesinde yüksek seviyede korunması ve kalitesinin yükseltilmesi belirtilmiştir. Bu noktada sürdürülebilir kalkınma olgusuna çevrenin bu şekilde konumlandırılması son derece önemlidir (TA, 1997: 7).

Avrupa Birliği Konseyi, 2000 yılında ekonomik ve sosyal yenilik için ekonomik büyüme ve istihdamı arttırmayı amaçlayan Lizbon Stratejisi adında bir dizi yapısal reform yayınlamıştır. Bu 10 yıllık strateji Avrupa'yı " Dünyanın en rekabetçi ve dinamik bilgi tabanlı ekonomisi" yapmayı amaçlamaktadır (IEEP, 2010: 87).

\subsubsection{Lizbon Stratejisi}

Lizbon stratejisi özellikle yenilik yaratmanın ve teknolojik gelişmenin ekonomik değişimin motoru olduğu fikri üzerine inşa edilmiş ve küresel rekabet gücünün Ar-Ge ve bilgi teknolojileri alanlarında fark yaratılmasıyla elde edilebileceğini belirtmiştir. Bunun yanında, Birlik politikalarının odak noktasının insan olduğundan yola çıkarak "İnsana yatırım yaparak aktif refah devleti" oluşturulmasına dayanan sosyal bir model benimsenmiştir (Çapanoğlu, 2010:1).

$\mathrm{Bu}$ hedeflere bir yıl sonra Göteborg'daki Avrupa Konseyi tarafindan çevre ve sürdürülebilir kalkınma boyutu kazandırılmışıı. Bu kazanımla beraber Lizbon Stratejisi, Avrupa Birliği'ni ekonomik, sosyal ve çevresel yenilik getirmeyi amaçlayan tek bir hedef noktasında toplamıştır. Göteborg Avrupa Konseyi'nin anlaşmaya vardığı sürdürülebilir kalkınma stratejileri kapsamında çevre ile ilgili yer alan öncelikler: çıkarılması,

- Yenilenebilir kaynaklardan üretilen elektriğin 2010 yılına kadar \%22 seviyesine

- GSYİH ve ulaşımdaki büyüme arasındaki bağı ayrıştırarak ulaşımı özellikle diğer taşıma metotlarına doğru kaydırarak çevre dostu altyapı yatırımlarına öncelik vermek,

- Yükselen trafik hacimleri, tıkanıklık, gürültü ve kirlilik ile mücadele,

- Kaynak kullanımı ve büyüme kaynaklı atıkların arasındaki bağın ayrıştırılması,

- Güvenlik ve gıda kalitesi, kimyasal madde kullanımı, enfeksiyon hastalıkları, antibiyotik direnci hakkında vatandaşların bilgilendirilmesi,

- Sera gazı emülsiyonlarının 2005 yılına kadar gözle görülür şekilde azaltılması (Örnek: Kyoto Hedefleri),

- 2010 yılına kadar biyolojik çeşitlilik kaybının durdurulması şeklinde belirtilmiştir (Ungureanu and Marcu, 2006: 74-79).

Lizbon Stratejisi'nin uygulamaya başlanmasından sonra 2005 yılında yapılan ara dönem değerlendirmesinde, başta istihdam ve sosyal güvenlik olmak üzere, öngörülen hedeflere ulaşılamadığı sonucuna varılmıştır. Avrupa Komisyonu Lizbon Stratejisi'nden yola çıkarak yeni ve daha ileri bir perspektifle mevcut stratejinin yerini alacak "AB 2020" olarak adlandirllan yeni bir strateji ortaya koymuştur (Çapanoğlu, 2010: 1-2). 


\subsubsection{Avrupa 2020 Stratejisi}

Avrupa 2020 Stratejisi, Lizbon Stratejisi’nde yaşanan başarısızlıklardan ders çıkarılarak, 10 yıllık süreç için, AB’yi ekonomik krizin olumsuz etkilerinden arındırmak ekonomik büyüme, istihdam ve çevre ile ilgili hedeflerini gerçekleştirmek için yeni bir yol haritası olarak tasarlanmıştır.

Strateji, akıllı, sürdürülebilir ve kapsayıcı büyüme olarak belirlenen üç temel ayaktan oluşmaktadır.

- Akıllı Büyüme: Avrupa Birliği’ni bilgiye ve yenilikçiliğe dayalı bir ekonomiye dönüştürmek, birlik içindeki eğitim kalitesini iyileştirmek, araştırma çalışmalarını güçlendirmek ve bilgi transferini sağlama yoluyla yenilikçi fikirlerin ekonomik büyüme, istihdam yaratıcı ürün ve hizmetlere dönüştürülmesini hedeflemektedir (Akbaş ve Apar, 2010: 4)

- Sürdürülebilir Büyüme: Kaynakları daha verimli kullanan, daha çevreci ve daha rekabetçi bir ekonominin temellerini atmak olarak tanımlanmaktadır. AB'yi düşük karbonlu ve kaynaklar açısından daralmış bir dünyada çevresel azalmayı engelleyici, biyo-çeşitliliği koruyucu ve kaynakların israfını önleyici bir noktada konumlandırmayı hedeflemektedir (Akbaş ve Apar, 2010: 5)

- Kapsayıcı Büyüme: Avrupa Birliği’ni sosyal ve bölgesel uyumu sağlamış yüksek istihdamlı bir ekonomiye dönüştürmeyi hedeflemektedir (IKVV, 2014: 33).

Avrupa 2020 Stratejisi kapsamında, Avrupa Birliği'nin çevrenin korunmasına ve iklim değişikliğiyle mücadeleye yönelik hedefleri:

- Sera gazı salınımlarının 1990 yılı seviyesine kıyasla en az yüzde 20 oranında azaltılması (diğer gelişmiş ve gelişmekte olan ülkeler de bu yönde girişimlerde bulundukları takdirde, bu oranın yüzde 30'a ulaştırılabileceği de belirtilmiştir);

- Yenilenebilir enerjinin Avrupa Birliği’nin toplam enerji tüketimindeki payının yüzde 20'ye çıarılması,

- Enerji verimliliğinin yüzde 20 artırılması olarak belirlenmiştir.

Avrupa Komisyonu bu hedefleri belirlemiş olmasına rağmen, şirketlerin iş yapma ortamını iyileştirmeye yönelik somut hedef belirlememiştir (IKVV, 2014: 95).

\section{3. Çevre Eylem Programları}

Avrupa Birliği, çevre politikasını uzun süre topluluk içindeki problemlerin çözümüne odaklı olarak kurgulamıştır. Ancak daha sonra kirliliğin küresel olma özelliğinin yanı sıra bölgesel ve uluslararası düzeyde ortak ve uyumlu hareket etme gereğinin farkına vararak daha kapsamlı politikalar geliştirmiştir.

1972 yılında Paris’te yapılan zirvede ilk adımları atılan Çevre Eylem Programları, genellikle Konsey beyanı olarak kabul edilen, hukuki bakımdan bağlayıcı olmayan, ama politik bakımdan belirli niyetleri ortaya koyan çalışmalardır. Programlar, kirlilik ile mücadeleyi, çevreye ilişkin konuların tüm aktivitelere entegre edilmesini amaçlamaktadır (Durmaz, 2004: 7). Topluluk günümüze kadar toplam 7 Çevre Eylem Programı yayınlamıştır.

\subsubsection{Birinci Çevre Eylem Programı (1973-1976)}

Çevre politikalarının amaç ve ilkelerini belirleyen birinci eylem programında yapılacak eylemler anlatılmıştır. Programın temel amacı "Ulusal çevre politikalarının, olabildiğince 
birbirine uyumlu hale getirilmesi ve koordine edilmesidir" (Dura ve Atik, 2014: 437). Program altı ana amaç etrafında şekillenmiştir. Bunlar:

- Çevreyi kirletmenin ve zarar vermenin önlenmesi veya en aza indirilmesi,

- Tatminkar bir ekolojik denge ve biyosfer korumasını kalıcı hale getirmek

- Ekolojik dengeye zarar verecek derecede kaynakların veya doğanın kullanımına mani olunmas1,

- Yaşamın ve özellikle çalışma hayatının iyileştirilmesi için gerekli kalite ve düzenlemelerin oluşturulması,

- Yerleşmenin planlanması ve toprağın kullanımında düzenleme yapılması,

- Özellikle uluslararası kuruluşlarla ve topluluğun dışındaki ülkelerle, çevre sorunlarının çözümü için işbirliği yapılması şeklindedir (TUSİAD, 1998: 56). Bu hedeflerden çoğu daha sonra Avrupa Tek Senedi ve Maastricht Antlaşması'nda yer almıştır.

Birinci Çevre Eylem Programı'nın genel prensipleri on bir başlık halinde verilmiş̧ir. Bu başlıklar kısaca:

- Kirliliğin kaynağında önlenmesi,

- Bütün teknik planlama ve karar alma süreçlerinde çevre boyutunun en erken aşamada dikkate alınması,

• Ekolojik dengeye büyük zarar veren doğal kaynakların ya da doğanın sömürülmesinden kaçınılmalıdır,

- Bilimsel ve teknolojik araştırmaların çevreyi korumak ve geliştirmek ve kirlilikle mücadele etmek kapsamında desteklenmesi,

- Ortaya çıkmış olan sorun maliyetinin kirleten tarafından karşılanması,

- Birlik içindeki bir ülkede yapılan aktivitenin, başka bir ülkede çevresel bir yıkıma yol açmamas1,

- Birlik içinde gelişen çevre politikalarının gelişmekte olan ülkelerin durumlarının da dikkate alınarak şekillendirilmesi,

- Küresel çevre araştırma ve politikalarını teşvik etmeyi amaçlayan girişimlerin uzun dönemli Avrupa Çevre Politikasının tanımlandığı şekilde arttırılması,

- Çevrenin korunması bütün birlik için önemlidir ve çevre politikasının başarısı için bütün seviyelerdeki herkes destek olmalı, konuyla ilgili olarak devamlı ve detaylı eğitimler verilmelidir.

- Her kategorideki kirlilik için farklı seviyeler tespit edilerek öncelikler belirlenmelidir,

- Çevre politikasının ana bakış açısı bazı ülkelerle sınırlı kalmamalıdır. Uzun vadeli ortaklık anlayışı çerçevesinde, bu alandaki ulusal programlar koordine edilmeli ve ulusal politikalar birlik içinde harmanlanmalıdır şeklinde özetlenebilir (FEAP, 1973: 6-7).

Günümüzde bu programın bazı amaç ve ilkeleri geçerliliğini korurken, bazıları ise geçerliliğini yitirmiştir. Birinci Eylem Programı'nın en büyük katkılarından birisi Birliğin çevre koruma yaklaşımındaki gelişme olmuştur (FEAP, 1987: 6). 


\subsection{2. İkinci Çevre Eylem Programı (1977-1981)}

İkinci Eylem Programı, Birinci Programın devamı ve genişletilmiş şeklidir. Yürürlükte kalacağı beş yıllık süreçte Komisyon'un çevre mevzuatını hazırlamaya devam etmesi öngörülmüş ve bu dönemde birçok yeni tasarı ve karara imza atmıştır (Budak: 2000: 225-227).

Birinci programdaki faaliyetlerin daha somut olarak ele alındığı İkinci Eylem Programı, çevre politikaları ile istihdam ilişkilerine ağırlık vererek çevre finansmanı üzerinde durmuştur. "Çevresel Etki Değerlendirmesi” (ÇED) ilk defa burada gündeme gelmiştir (Dura ve Atik, 2014: 437).

\subsection{3. Üçüncü Çevre Eylem Programı (1982-1987)}

Üçüncü Program ilk iki programa göre daha geniş perspektifte ele alınmıştır. Program içerisinde özel konulara odaklanmak yerine daha genel bir anlayış hakim olmuştur.

Çevre politikası topluluğun genel, sosyoekonomik düzeninin yapısal bir unsuru olduğunu kabul ederek, tedavi etmek yerine önleyici politikaları tercih ettiğini ortaya koymuştur (Budak: 2000: 230).

Programda ayrica:

- Çevre boyutunun diğer programlarla entegrasyonu,

- Çevresel etki değerlendirme prosedürü,

- Akdeniz Bölgesi'ndeki çevresel koruma,

• Özellikle ulaşım kaynaklı ses kirliliği

- Sınır ötesi kirlilik ile mücadele,

- Tehlikeli kimyasal maddeler,

- Atık yönetimi,

- Temiz teknoloji gelişiminin teşvik edilmesi,

- Topluluk açısından önem taşıyan özellikle hassas çevre alanların korunması,

- Çevre ile ilgili olarak gelişmekte olan ülkelerle işbirliği konularına öncelikli olarak yer verilmiştir (TEAP, 1983: 2).

Bunun yanında çevre politikasının ilgilenmek zorunda olduğu konular:

- Daha az kirleten ve kaynak kullanan sanayinin teşvik edilerek istihdam alanlarının yaratılmas1,

• Geri dönüşümü olmayan atıkların idareli kullanılması ve daha az kirleten alternatiflerin ortaya çıkarılması,

- Nükleer enerji, kömür ve petrole olan bağımlılığın azaltılması, enerji verimliliğinin sağlanması ve daha az kirleten enerji kaynaklarının özendirilmesi olarak belirtilmiştir (TEAP, 1983: 4).

\subsubsection{Dördüncü Çevre Eylem Programı (1987-1992)}

Avrupa Tek Senedinde ifade edilen politikalar çerçevesinde oluşturulan program, kaynakların ve çevrenin korunması amacıyla sorunları daha bütün olarak ele almış ve önleyici 
politikalara ağıllık vermiştir. Programın içeriğinde 1987 yılının Avrupa Çevre Yılı olarak seçildiği belirtilmiştir.

Kirliliğin önlenmesi ile ilgili olarak 22 maddeye yer verilmiştir. Bu maddeler daha önceki programda ifade edilen maddelere benzer bir içerik taşır. Genel olarak bakıldığında tanıtım ve sonuç bölümlerinin haricinde 6 bölümde ele alınmıştır. Bunlar:

- Genel Politika Yönelimleri,

- Kirliliğin Önlenmesi ve Kontrolü Yaklaşımı,

- Belirli Sektörlerdeki Eylemler,

- Çevresel Kaynakların Yönetimi,

- Araştırma,

- Uluslararası Düzeyde Eylem,

- Avrupa Çevre Y1lı'dır (FEAP, 1987: 5).

\subsubsection{Beşinci Çevre Eylem Programı (1993-2000)}

Avrupa Birliği Çevre Politikasının esaslarını belirleyen programın giriş bölümünde sürdürülebilir kalkınma ve çevre ilişkisi açıklanmıştır. Maastricht antlaşmasında ifade edilmiş olan sürdürülebilirlik kavramına kalkınma kavramı da eklenerek bütüncül bir hale getirilmiştir. Bu bütüncül hal daha sonra Amsterdam Antlaşmasında da vücut bulmuştur.

Program önceki programlara göre birçok çevresel sorunu çok daha kapsamlı şekilde ele almıştır. Bu sorunlar genel olarak şu şekilde verilmiştir:

- İklim Değişikliği,

- Asitleşme ve hava kirliliği,

- Doğal Kaynak tüketimi ve bioçeşitlilik,

- Su kaynaklarının kirliliği ve tüketimi,

- Kentsel çevrenin bozulması,

- Kiyı alanlarının bozulması,

- Atık (FEAP, 1993: 13).

AB'nin, birlik politikalarını çevrenin korunması ilkesi ile bütünleştirme çabasına bağlı olarak, yürütülen bütün çalışma ve programlarda çevrenin de göz önüne alınması artık zorunlu olmuştur (Dura ve Atik, 2014: 438).

\subsubsection{Altıncı Çevre Eylem Programı (2001-2010)}

"Çevre 2010: Geleceğimiz, Tercihimiz" adıyla anılan Altıncı Çevre Eylem Programı, dört ana öncelik üzerine kurulmuştur. Bunlar:

- İklim Değiş̧ikliği,

- Doğa ve Biyolojik Çeşitlilik,

- Çevre ve Sağlık ve Yaşam Kalitesi,

- Doğal Kaynaklar ve Atıklardır (SEAP, 2002: 3). 
Programda bahsedilen sürdürülebilir kalkınma, pazar ekonomisinin güçlendirilmesi, serbest piyasayı düzenleyici kurallara yer verilmesi, çevre sorunlarının geniş kapsamlı bakış açısıyla ele alınması, çevre duyarlılığının yaygınlaştırılıp katılımın arttırılması gibi başlıklara bakıldığında büyük ölçüde 5. Programla uyum sağladığı görülmektedir.

Kullanılmakta olan mevzuatın iyileştirilmesi, piyasa ile yakın çalışma, çevre gereklerinin diğer politikalara entegre edilmesi, arazi kullanımının planlanması ve idari kararlarda çevre konusunun dikkate alınması, kişilerin özel vatandaşlar olarak güçlendirilmesi ve onların davranışlarını değiştirmede yardım edilmesi olarak ifade edilen beş öncelikli konu belirtilmiştir. Bunlara ek olarak AB'nin aday ülkelerle diyalog ve STK'ların bu kapsamda etkinleştirilmesi gerektiğine de yer verilmiştir (Bozkurt, 2010: 118-119).

\subsubsection{Yedinci Çevre Eylem Programı (2013-2020)}

Program, 2020'ye kadar öncelikli hedeflerini özetlemekte ve 2050 y1lı için esas sorunlara yönelik uzun vadeli bir görüş sunmaktadır. Ayrıca Avrupalıların ekonomik başarısının ve refahının, doğal sermayesinin sağlık durumuna bağlı olduğu anlayışı üzerine kurulmuştur (Bruyninckx, 2014: 1).

“Gezegenin Sınırları İçinde, Daha İyi Yaşamak" sloganıyla, yayınlandıktan bir yıl sonra yürürlüğe giren program kapsamında dokuz öncelik belirtilmiştir. Bunlar:

- Birliğin doğal sermayesinin korunması, muhafaza edilmesi ve güçlendirilmesi,

- Birliğin kaynak-verimli, yeşil, rekabetçi düşük karbon ekonomisine geçişinin sağlanmas1,

- Birlik vatandaşların sağlık ve refahının çevre ile ilgili risklere karşı korunması,

- Birlik Çevre Mevzuatının uygulanmasının geliştirilmesi,

- Birlik Çevre Mevzuatına yönelik bilgi ve deneyimin artırılması,

- Çevre ve iklim politikaları için gerekli yatırımın sağlanması,

- Çevrenin diğer politika alanlarına entegrasyonun ve politikalarda tutarlılığın sağlanması,

- Birlikteki şehirlerin sürdürülebilirliğinin güçlendirilmesi,

- Birliğin uluslararası çevre ve iklim sorunları konusundaki etkinliğinin güçlendirilmesidir (SEAP, 2013: 174).

Belirlenen bu dokuz öncelik, kendi içerisinde temel, kolaylaştırıcı ve ek yatay öncelik olarak sinıflandırılmaktadır. Bu sinıflandırılmaya göre:

\section{Temel Hedef:}

- Doğal Sermaye,

- Kaynak Verimli Ekonomi: Daha az ile daha fazlasını gerçekleştirme

- Sağlıklı Çevre ve İnsan: Çevreye özen göstermek kendimize özen göstermektir.

AB'nin temel hedeflerine ulaşması için kolaylaştırıcı olarak tanımlanan hedefler (4I):

- Gelişmiş Uygulamalar: Çevre, sağlık ve bütçemiz için iyi olan,

- Artan Bilgi: En son verilere dayanan en iyi kararlar,

- Güvenli Yatırımlar: Yeşil teşvikler, yeşil yenilikler demektir,

- Daha İyi Entegrasyon: Bir yaklaşım ile çeşitli zorluklarla mücadele, 


\section{Iki ek yatay öncelik hedefleri:}

- Sürdürülebilir Şehirler: Ortak çözümler için birlikte çalışma,

- Uluslararası Zorluklarla Mücadele: "Gezegenimizin sınırları içinde iyi yaşamak (EC, 2016).

Programla beraber AB'nin diğer politika alanlarını ilgilendiren "Entegre çevre yönetiminin esasları", geniş bir yelpazede üye ülkelere sunulmaktadır. Çevre-dostu üretim modellerinin yaygınlaştırılmasına ön ayak olan bir "iş dünyası" ile bu ortamın getirisi olarak uzun vadeli yeni iş imkânlarının yaratılması temel hedefler arasında yer alarak AB'de hızla gelişen yeşil ekonomiye geçişi hızlandıracak çalışmalara ağırlık verileceği düşünülmektedir (K1vilc1m, 2014: 1).

\section{TÜRKIYYE'DE ÇEVRE POLITTIKALARININ TARIHSEL GELISŞIMİ}

Türkiye, Cumhuriyet döneminin ilk yıllarında savaş sonrası yeniden yapılanma çabasına girmiş, bu çerçevede ekonomik ve politik önceliğini başka konulara ayırarak çevre konusuyla ilgili girişimlerini halk sağlığı çerçevesinde kısıtlamıştır.

Avrupa Birliği ve dünyada olduğu gibi Türkiye'de de 1960'lı yıllara kadar çevre konusunda çok önemli düzenlemelere rastlanmamaktadır. Hızlı sanayileşme faaliyetlerinin ciddi çevre sorunlarına sebep olduğunun henüz fark edilmemesine bağlı olarak benimsenen bir çevre politikasının oluşmadığı, bütüncül bir düzenleme yerine her kanunun kendi ilgi alanlarıyla ilgili yasaklara, düzenlemelere yer verdiği görülmektedir (Sencar, 2007: 108).

Türkiye, ekonomik ve sosyal kalkınmasını hızlandırmak için 30 Eylül 1960 tarihinde Devlet Planlama Teşkilatını kurmuş, üç yıl sonra 1963 yılında ilk Beş Yıllık Kalkınma Planını yayınlayarak kalkınma ve sanayileşme çabalarını planlama anlayışı ile şekillendirmeye başlamıştır. İlk planlarda çok fazla olmasa da yıllar içerisinde kalkınmanın vermiş olduğu çevre tahribatı ve uluslararası anlaşmaların ilkeleri doğrultusunda çevre konusuna kalkınma anlayışı içerisinde yer vermiştir.

\subsection{Birinci Beş Yıllık Kalkınma Planı (1963-1967)}

"Milli tasarrufu artırmak, yatırımları toplum yararına, gerektirdiği önceliklerle yöneltmek ve iktisadi, sosyal ve kültürel kalkınmayı demokratik yollarla gerçekleştirmek üzere" imzalanan Birinci Beş Yıllık Kalkınma Planı, halkı mümkün olduğunca geniş bir perspektifte yüksek bir yaşam standardına ulaştırmayı hedeflemektedir (BBYKP, 1963: 1). Bu hedef çerçevesinde henüz herhangi bir çevre farkındalığının oluşmaması nedeniyle çevre konusuna değinilmemiştir.

Bu dönemde Türkiye-Topluluk ilişkilerinde öne çıkan husus 12 Eylül 1963 yılında AET ile bir ortaklık ilişkisi yaratan Ankara Antlaşması'nın imzalanması ve 1 Aralık 1964 yılında Ankara Antlaşmasının yürürlüğe girmesi olmuştur (AB, 2016: 1).

\section{2. İkinci Beş Yıllık Kalkınma Planı (1968- 1972)}

İkinci Plan, birinci plana benzer şekilde bölgesel planlama anlayışı içerisinde hazırlanmıştır. Birinci Beş Yıllık Kalkınma Planı'ndaki bölgelerarası gelişmişlik farklarını azaltıcı yöndeki politikaların daha somutlaştırılarak tekrarlandığı bu plan (Dinler, 1998: 207), beraberinde zamanla ortaya çıkacak bir nüfus artış1, göçün neden olduğu metropollerde kalabalıklaşma ve sanayinin gelişmesini getirmiştir. 
1970’li yıllarda çevre konusunda Avrupa'da ortaya çıkan bilinç, ikinci kalkınma planında yer bulmamıştır. İkinci planı çevre konusunda önemli kılan ayrıntı aldığı önlemler değil, çevre konusunun önemli bir hale gelmesine neden olan politikaların daha kararlı bir şekilde devam ettirmesi olmuştur.

Topluluk ile ilişkilere bakıldığı zaman 23 Kasım 1970 yılında Gümrük Birliği'ne ilişkin kuralları içeren Katma Protokol'ün imzalandığı ve 1 Eylül 1971 yılında Katma Protokol'ün ticari hükümlerinin "Geçici Anlaşma" ile yürürlüğe konulduğu göze çarpmaktadır (AB, 2016: 1).

\section{3. Üçüncü Beş Yıllık Kalkınma Planı (1973-1977)}

Üçüncü Beş Yıllık Kalkınma Planı döneminde çevre sorunları gelişmiş ve gelişmekte olan ülkeler için farklı şekilde nitelendirilmiştir. Gelişmiş ülkeler sanayi faaliyetlerinin yoğunluğu, yıllar boyu doğal kaynak kullanımındaki aşırılık ve sorumsuz tutumun sonucu olarak ortaya çıkan çevre sorunlarıyla karşılaşmıştır. Gelişmekte olan ülkeler ise teknolojik yetersizlik, doğal kaynakları yeterince kullanamama, yetersiz eğitim ve gelir düzeyleri sonucu doğa ile uyumlu bir ilişki kurulamama noktasındaki sorunlarla karşılaşmıştır (ÜBYKP, 1973: 866), (Budak, 2000: 426).

Planın 25. bölümünde Çevre Sorunları ile ilgili bir bölüme yer verilmiş ve bu kapsamda sorunu gelişmekte olan ülkelerin kalkınma sorunları dışında görmenin mümkün olmadığı belirtilmiştir. Bunun yanında bu sorunları ileri sürerek kalkınma çabalarının yavaşlatılmasının da geçerli olamayacağı ifade edilmiştir. Bazı sanayileşme projelerinde ve yoğun kentleşme alanlarında hava, su ve kıyıların kirlenmesinin dar anlamda görüldügü kabul edilerek bunun ülkenin bütünü için geçerli olmadığı fakat erozyon ve çevre sağlığı gibi doğal kaynakların gerekli biçimde ve yeterince kullanılamamasına ya da gelir ve eğitim yetersizliğine dayanan sorunların öteden beri var olduğu kabul edilmiştir (ÜBYKP, 1973: 866).

$\mathrm{Bu}$ anlayış çerçevesinde ilkeler ve alınması gereken tedbirler belirlenmiştir. Çevre ve insan ilişkilerinin rasyonel bir dengeye ulaşmasının yolu sosyal ve ekonomik kalkınma olarak ifade edilmiş, sorunların çözümü ile ilgili olarak uluslararası düzeyde sürdürülecek çalışma ve yasal düzenlemelerde Türkiye'yi sanayileşerek kalkınma hedefinden saptıracak hiçbir uygulamanın kabul edilmeyeceği belirtilmiştir (ÜBYKP, 1973: 867).

Çevre sorunlarının tespiti için birtakım önlemlerin alınması, uluslararası araştırmaların izleneceği, ilkeler çerçevesinde düzenlemeler yapılacağı ve toplumun eğitileceği kararlaştırılmış olsa da üçüncü planda öne çıkan unsur, Türkiye'nin kalkınma önceliğinden taviz vermeden yapılabilecekler olarak karşımıza çıkmaktadır.

Plan çerçevesinde Türkiye çevre politikalarını kendi kalkınma çabaları içerisinde şekillendirirken, AB'de Birinci Çevre Eylem Programı kapsamında Birliğin çevre koruma yaklaşımını geliştirmeye başlamıştır. Bu açıdan bakıldığı zaman plan içerisinde yer alan bazı önlemlerin bütünüyle olmasa da topluluk politikalarıyla uyumlu bir süreç izlediği söylenebilir.

Bir başka önemli husus, bu gelişmeler yaşanırken Türkiye ile $\mathrm{AB}$ arasındaki ilişkilerin ne düzeyde olduğudur. $\mathrm{Bu}$ düzey, Türkiye'nin $\mathrm{AB}$ politikalarına uymaya çalıştığı ya da ertelediği durumlarda politikaların nasıl şekillendiğinin görülmesi açısından önem taşımaktadır.

Bu süre zarfında Türkiye ile Topluluk arasında 21 Mayıs 1973 tarihinde genişleme görüşmeleri mutabakat ile sonuçlanmıştır. 30 Haziran 1973 tarihinde I. Genişleme Anlaşması (Tamamlayıcı Protokol) Ankara'da imzalanmıştır.1 Ocak 1976'da Türkiye, Katma Protokol'den kaynaklanan yükümlülüğünü yerine getirerek ikinci gümrük indirimi ve konsolide liberasyon listesi uyumunu gerçekleştirmiştir ve 12 Mayıs 1977'de III. Mali Protokol Brüksel'de imzalanmıştır (AB, 2016: 1). 


\subsection{Dördüncü Beş Yıllık Kalkınma Planı (1979- 1983)}

Dördüncü Planda çevre sorunlarına dördüncü bölümde bölgesel gelişme ve yerleşme başlı̆g 1 altında yer verilmiştir. Üçüncü planda ana politika olarak kabul edilen çevre sorunlarının sanayileşme ve kalkınmadan soyutlamaksızın çözümü bu ilk maddede tekrar vurgulanarak 19731977 döneminde konuyla ilgili olarak kamuoyu bilinçlenmesinin oluştuğu ve sorunların tanımlandığı ifade edilmiştir.

Türkiye'de görülen kirliliğin ileri toplumlarda rastlanan çevre kirliliği olduğunu, bunun yanında geleneksel kesimdeki su, kanalizasyon sorunu, gecekondu bölgelerindeki kötü barınma koşulları, toprak ve orman erozyonun da görüldüğü ifade edilmiştir. Su, deniz, hava, toprak erozyonu kirlenmesi ile ilgili olarak tespitler yapılmış, su kirlenmesini önlemeye yönelik yasal düzenlemeler yapılmış olmasına rağmen işlerlik sağlanamadığı belirtilmiştir (DBYKP, 1979: 83$85)$.

Planın ikinci kesim ekonomik ve toplumsal hedefler ve politikalar başlığının üçüncü bölümünde dördüncü planın temel politikalarından bahsedilmiştir. Planın dokuzuncu bölümünü oluşturan "Kentleşme ve Belediyeler" başlığının altında çevre sorunlarına tekrar yer verilmiştir. $\mathrm{Bu}$ kapsamda ilk olarak çevre sorunlarının temel ilkesi toplumsal değişim süreci ile birlikte çözüme kavuşturulması olarak ifade edilmiştir (DBYKP, 1979: 83-85).

Sorunun yaratılmadan önlenme aşamasında çözüme kavuşturulmasına ağırlık verileceği, mevcut çevre sorunlarını giderici yaklaşımlarda alternatif çözüm önerilerinin dikkate alınarak sosyoekonomik ve ekolojik yapıya en uygun çözümler seçileceği belirtilerek bir çeşit bölgesel çevre politikasından bahsedilmiştir (DBYKP, 1979: 297).

Çevre sorunları konusunda çalışan vakıf, dernek ve benzeri gönüllü kuruluşların plan doğrultusundaki faaliyetlerinin destekleneceği, çevrenin turizm açısından değerlendirileceği, özellikle büyük kentlerde halkın kullanımına uygun çevre alanlarının oluşturulacağı ve uluslararası alanda yasal, bilimsel ve teknolojik gelişmelerin takip edileceği belirtilmiş̧tir (DBYKP, 1979: 297).

Dördüncü plan döneminde toplulukta İkinci Çevre Eylem Programı kabul edilmiştir. Birinci Çevre Eylem Programının devamı niteliğinde olan programa bakıldığı zaman sorunun yaratılmadan önlenme, her kirlilik için farklı önlem, bilimsel ve teknolojik gelişmenin takibi gibi konularda birliğe uygun politikaların benimsenmeye çalışıldığı görülmektedir. $\mathrm{Bu}$ açıdan bakıldığında dördüncü planın kendinden önceki planlara nazaran $\mathrm{AB}$ çevre politikasını şekillendiren programlara daha uyumlu olduğu söylenebilir

Dördüncü Kalkınma Planı dönemine, Topluluk ile olan ilişkiler açısından baktığımız zaman en önemli olayın 22 Ocak 1982 yllında Avrupa Parlamentosu'nun, Konsey ve Komisyon'dan talebi üzerine, Türkiye-AET Anlaşması'nın askıya alınmasının kararlaştırılması olduğunu söylemek mümkündür ( $\mathrm{AB}, 2016: 1)$. Bu kararın kalkınma planının oluşturulmasında herhangi bir etkisi olup olmadığını bir sonraki planda görmek, dördüncü planın uygulanma dönemine denk geldiği için, daha mümkün olacaktır.

Son olarak Dördüncü Kalkınma Planı döneminde yer alan önemli bir gelişmeden daha bahsetmek gerekmektedir. 1982 anayasasının 56. Maddesi "Sağlık Hizmetleri ve Çevrenin Korunması" başlığı altında "Herkes, sağlıklı ve dengeli bir çevrede yaşama hakkına sahiptir. Çevreyi geliştirmek, çevre sağlığını korumak ve çevre kirlenmesini önlemek Devletin ve vatandaşların ödevidir." metni anayasal bir çerçevede bağlayıcı olarak yer almıştır (TBMM, 2011: 114). 


\subsection{Beşinci Beş Yıllık Kalkınma Planı (1985-1989)}

Beşinci Planın dördüncü bölümünün on yedinci kısmı çevre sorunlarının ilke ve politikalarına ayrılmıştır. Bu ayrılmış bölümün haricinde enerji sektöründeki ana politikaların belirlenmesinde kaynakların ve çevrenin de korunmasına değinilmiş, çevre kirlenmesine olanak sağlamayan uluslararası araştırmaların da takip edilmesi gerektiği belirtilmiştir. Turizm ile ilgili olan politikalar da ekolojik dengeyi korumak, çevreyi temiz ve sağlıklı tutmak ve güzelleştirmek çerçevesinde değerlendirileceği ifade edilmiştir. Kamu kurumlarının yatırım projelerinde çevresel etkinin göz önünde bulundurulması ve raporlarında "Çevresel Etki İrdelemesi" raporlarının hazırlanacağına yer verilmiştir (BBYKP, 1985).

Plan ayrıca çevre sorunlarının temelini belirten bir yaklaşıma yer vermiştir. Bu yaklaşım çerçevesinde Türkiye'deki çevre sorunları "Şehirleşme, erozyon ve tabii afetlerin sonucu olan çevre kirlenmeleri ile hızlı sanayileşmenin ve tarımda modernleşmenin getirdiği çevre sorunları" olarak ifade edilmiştir. Bu bağlamda temel yaklaşım mevcut kirliliğin ortadan kaldırılması değil, kaynakların gelecek nesillerin de yararlanabileceği en iyi şekilde kullanılması, muhafazası ve geliştirilmesi olarak belirtilmiştir.

$\mathrm{Su}$ kalitesinin değerlendirilmesine ve su kaynaklarının kullanımında rasyonel bir düzenlemeye önem verileceği, su kirlenmesinin aşırı olduğu yerlerde sanayilerin gerekli tedbirleri alacağı, sanayi atıklarının denetleneceği, içme suyu ile ilgili düzenlemeler yapılacağı ve çevre alanında sürdürülmesi gerekli olan araştırma ve geliştirme faaliyetlerine öncelik tanınarak ilgili üniversite ve kuruluşların destekleneceği ifade edilmiştir (BBYKP, 1985: 171).

Beşinci Kalkınma Planı, Topluluğun Üçüncü Çevre Eylem Planının uygulandığı döneme denk gelmektedir. Üçüncü Çevre Eylem Planının da yer alan "Çevresel Etki Değerlendirme Prosedürü”, nükleer enerji, kömür ve petrole olan bağımlılığın azaltılması, enerji verimliliğinin sağlanması ve daha az kirleten enerji kaynaklarının özendirilmesi, atık yönetimi gibi topluluğun öncelikli konularına Beşinci Kalkınma Planında topluluğa uyumlu olarak yer verildiği görülmektedir.

Beşinci Plan döneminde Topluluk, çevre planlarında yer alan hükümlerine, 1986 Yılında imzalanan ve Üçüncü Çevre Eylem Planı döneminin sonu olan 1987 yılında yürürlüğe giren Avrupa Tek Senedinde yer vermiştir. Türkiye' de ise bu dönemde kalkınma planlarında yer alan çevre ile ilgili ifadeler Çevre Kanununda yer almamıştır (Budak, 2000: 432).

Dördüncü kalkınma Planına denk gelen Türkiye-AET Anlaşması'nın askıya alınması kararının Türkiye'nin topluluk politikalarına uyum sürecine bir etki yaratmadığı ve Türkiye'nin AB'ye tam üyelik hedefinden sapmadığ 1 bu çerçevede ifade edilebilir. Çevre kapsamında kalkınma planları içerisinde toplulukla uyumlu adımların atılması bunun somut bir örneğini oluşturmaktadır.

$\mathrm{Bu}$ dönem içerisinde Topluluk ile olan ilişkilerin seyrine bakıldığında 16 Eylül 1986 tarihinde, 12 Eylül 1980 tarihinden itibaren fiilen dondurulmuş durumda bulunan Türkiye-AET ilişkilerinin yeniden canlandırılması süreci başlamış, 14 Nisan 1987'de Türkiye, Avrupa Topluluklarına, Roma Antlaşması'nın 237'nci, AKÇT Antlaşması'nın 98'inci ve EURATOM Antlaşması'nın 205'inci maddelerine istinaden tam üye olmak üzere ayrı ayrı müracaat edilmiştir. 18 Aralık 1989'da Avrupa Komisyonu, Türkiye'nin tam üyelik başvurusu konusundaki "Görüş̧"ünde (Avis), Topluluğun, kendi iç pazarını tamamlayabilme sürecinden önce (1992), yeni bir üyeyi kabul edemeyeceği ve Türkiye'nin katılımından önce, ekonomik, sosyal ve siyasal alanda gelişmesine ihtiyaç duyulduğu hususlarına yer vermiş̧tir (AB, 2016: 2). 


\subsection{Altıncı Beş Yıllık Kalkınma Planı (1990 -1994)}

Altıncı Beş Y1llık Planın dördüncü bölümünün dördüncü başlığı çevre ve yerleşme olarak belirtilmiştir. Bu başlığın içerisinde çevre sorunları, yerleşme-şehirleşme, konut ve içme suyukanalizasyon alt başliklar olarak yer almıştır.

Plan içerisinde, orman arazilerinin çevre unsurları dikkate alınarak yeniden düzenlenmesi, madencilik faaliyetleri sonucunda oluşan çevre sorunlarının giderilmesi için yasal düzenlemeler, sanayi kuruluşlarının çevre politikalarına uyumu, otomotivde çevre sorunlarını en aza indiren taşıtların üretimi, zehirli egzoz gazları ile ilgili yasal önlemlerin alınması, turizm yatırımlarında çevre ilkelerinin esas alınması ve çevre sağlığının geliştirilmesine yer verilmiştir.

Planda çevre sorunlarının temel ilkeleri "İnsan sağlığı ve doğal dengeyi koruyarak, sürekli bir ekonomik kalkınmaya imkan verecek şekilde doğal kaynakların yönetimini sağlamak ve gelecek nesillere insana yakışır bir doğal, fiziki ve sosyal çevre bırakmak" şeklinde ifade edilmiştir. Bu ifadede önemli olan husus çevre sorunlarına "sürekli bir ekonomik kalkınmaya imkan verecek şekilde" ibaresinin eklenmiş olmasıdır. Böylelikle çevrenin önemi, kalkınma önceliğinin arkasında yer almıştır (ABYKP, 1990: 312).

Topluluk çevre politikalarına "sürdürülebilirlik" kavramını ilk olarak 1992 yılında kabul edilen ve 1993 yılında yürürlüğe giren Maastricht Antlaşması ve 1993 yılında yürürlüğe giren 5. Çevre Eylem Planında yer vermişken, Türkiye bu kavrama Altıncı Beş Yıllık Kalkınma Planı içerisinde değinerek öncü bir yaklaşımda bulunmuştur.

Bütün ekonomik politikalarda çevre boyutunun dikkate alınması, çevre bozulmaları önceden tahmin edilerek gerekli tedbirlerin kirlilik meydana gelmeden alınması gerektiği, çevre standartları tespit edilirken uygulanabilir mevcut teknolojiler ve ülke şartlarının birlikte düşünüleceği, çevre verilerinin bir merkezden yönlendirilerek toplanacağı, çevreyi kirleten kimyasallar ile ilgili kontrollerin yapılması, iller bazında çevre risk değerlendirmesi yapılması, yenilenebilir enerji için Ar-Ge faaliyetlerine yön verilmesi ve AT çevre politikalarına uyum için başlatılan çalışmaların sürdürülmesi plan kapsamında belirtilmiştir (ABYKP, 1990: 313).

Türkiye'nin Altıncı Beş Yıllık Kalkınma Planını, Eylem Planlarının genelinde görülen ve Avrupa Tek Senedinde de ifade edilen önceden önlenmesi ilkesi ve kaynağında önleme ilkesine uyumlu olarak şekillendirdiğini ifade etmek mümkündür. Daha da önemlisi Türkiye'nin çevre politikalarını AT çevre politikalarına uyumlu olarak sürdüreceği açıkça belirtilmiştir.

Mevcut dönemle ilgili olarak Türkiye-AB ilişkilerine bakıldığında 6 Haziran 1990 yılında Avrupa Komisyonunun, Türkiye ile her alanda işbirliğinin başlatılması ve hızlandırılması konusundaki önlemleri içeren bir "İşbirliği Paketi" hazırlayarak Avrupa Konseyi'nin oluruna sunduğu ve 30 Temmuz 1994 yılında Avrupa Komisyonu'nun, Gümrük Birliği'nin, Türkiye-AT arasında 1963 yılında imzalanan Ankara Antlaşması'nda belirtildiği şekilde gerçekleşmesini sağlayıcı ilkeleri tespit ettiği görülmektedir (AB(b), 2016).

\subsection{Yedinci Beş Yıllık Kalkınma Planı (1996-2000)}

Yedinci Kalkınma Planı’nın üçüncü bölümünün beşinci kısmı “Çevrenin Korunması ve Geliştirilmesi”" başlığını taşırken mevcut durum, amaç, ilkeler ve politikalar, hukuki ve kurumsal düzenlemeler şeklinde üç alt başlıkta çevre kavramına yer verilmiştir.

Sürdürülebilir kalkınma anlayışının yaygınlaşmasına rağmen, çevrenin ve dünyanın geleceği ile ilgili tehlikelerin hala geçerli olduğu, fakat teknolojinin sağladığı imkanların çevre sorunlarının çözümü doğrultusunda kullanılmasıyla bu alanda büyük ilerlemeler sağlanabileceği belirtilerek, çevrenin başlı başına bir sektör niteliği kazandığı ve üretim, istihdam ve ticaret açılarından öneminin arttığının altı çizilmiş̧tir (YBYKP, 1996: 4-17). 
Mevcut Durumda; Altıncı Plandaki sürdürülebilir kalkınma yaklaşımın önemine rağmen uygulamada yetersiz olduğu, çevre konusundaki politikaları saptayan Çevre Bakanlığının yetersiz kaldığ uygun olarak kullanılmadığı belirtilerek genel olarak yetersizliklere yer verilmiştir (YBYKP, 1996: 189-191).

Amaç, ilkeler ve politikalar başlığında; "Sürdürülebilir kalkınma yaklaşımı doğrultusunda, insan sağlığı ve doğal dengeyi koruyarak sürekli bir ekonomik kalkınmaya imkan verecek şekilde doğal kaynakların yönetimini sağlamak ve gelecek kuşaklara insana yakışır bir doğal, fiziki ve sosyal çevre bırakmak" temel ilke olarak ifade edilmiştir. Bunun yanında daha önce ifade edilen yetersizliklerin önlenmesi adına alınması gereken önlemler üzerinde durulmuştur (YBYKP, 1996: 191).

Hukuki ve Kurumsal Düzenlemeler alt başlığında: “Anayasa'nın, çevre ile doğrudan ve dolaylı şekilde ilgili maddelerinde sürdürülebilir kalkınma ilkesi doğrultusunda düzenlemeler yapılması gerektiği” ifade edilerek 2872 sayılı Çevre Kanununun günün koşullarına göre revize edileceği belirtilmiştir (YBYKP, 1996: 194).

Planda çevre ile ilgili olarak; çevreye sektörel yaklaşımla bu alanlarda nitelikli personel yetiştirilmesine ağırlık verileceği, çevresel risk faktörlerinin azaltılması için sektörler arasında işbirliği programlarının geliştirileceği, sulama sistemlerinin çevre şartlarına uyumlu olarak gerçekleştirileceği, uluslararası pazarda çevre dostu ürünlerin önemi, sanayi yatırımlarında çevre koruma konularının esas alınacağı, çevre dostu teknolojilerinin yaygınlaştırılacağı ve Karadeniz Ekonomik İşbirliği kapsamında çevrenin ve özellikle Karadeniz'in korunmasına yönelik faaliyetlerin teşvik edileceği belirtilmiştir. (YBYKP, 1996: 29-87).

Tüketicilerin çevresel tehlikelerden korunması gerektiği, enerji verimliliğine atıfla çevresel etkilerin en aza indirilmesi, yatırımlarda çevresel etki değerlendirmesinin önemi, tarım ve turizm gibi sektörlerde çevresel etkilerin göz önünde bulundurulması yine çevre ile ilgili ifadeler arasındadır. Etkin bir çevre yönetimi için Ulusal Çevre Stratejisi hazırlanması Yedinci Planda öneminin vurgulanması gereken çok önemli bir gelişmedir. (YBYKP, 1996).

“Türk Mevzuatının AT Mevzuatına Uyumu İçin Gerekli Düzenlemeler" kapsamında çevrenin korunmasının esas alınacağı belirtilmiştir. Bunun yanında çevre standartlarının uluslararası standartlar, özellikle $\mathrm{AB}$ standartları doğrultusunda sürekli olarak güncelleştirilmesi gerektiği ve çevre sorunlarının çözümü için uygulanan politikalar ve alınan kararların $A B$ normları ve uluslararası standartlara paralel olmasının sağlanacağı planda açıkça belirtilmiştir (YBYKP, 1996).

Yedinci Beş Yıllık Kalkınma Planı genel olarak Çevre Eylem Programlarına özel olarak da Beşinci Çevre Eylem Programı ve Amsterdam Antlaşmasında belirtilen hususlara uyum sağladığı görülmektedir. Özellikle sürdürülebilir kalkınma perspektifinde çevre sorunlarına yaklaşımı son derece uyumludur. Plan içerisinde de açıkça görüldüğü gibi topluluk çevre politikalarına ülkenin büyümesi engellenmeden uyulmaya çalışılacağı ifade edilmiştir.

Yedinci Plan döneminde Türkiye-AB ilişkilerine bakıldığında 1 Ocak 1996 tarihinde “Geçiş Dönemi” tamamlanarak tam üyelik sürecinde "Son Dönem”e girilmiştir. 12-13 Aralık 1997'de Lüksemburg Avrupa Konseyi Zirve Toplantısında, AB'nin Beşinci Genişlemesine dair alınan kararda Türkiye'nin ismi aday ülkeler arasında yer almamıştır. 3 Mart 1998 tarihinde "Türkiye için Avrupa Stratejisi" başlıklı belge ilişkilerin geliştirilmesi için açıklanmıştır. 4 Kasım 1998'de daha sonra her yıl yayınlanacak olan ilk "İlerleme Raporu” yayınlanmış ve 11-12 Aralık 1999 yılında Helsinki Avrupa Konseyi Zirve Toplantısı'nda Türkiye'ye adaylık statüsü tanınmıştır. 4 Temmuz 2000 tarihinde Avrupa Birliği Genel Sekreterliği, Başbakanlığa bağlı olarak kurulmuştur (AB(b), 2016). 


\subsection{Sekizinci Beş Yıllık Kalkınma Planı (2001-2005)}

Sekizinci Planda "Çevre" başlığına sekizinci bölümün on üçüncü kısmında ve planın temel amaç ve stratejileri içindeki dördüncü kısmın on beşinci maddesinde yer verilmiştir. Genel çerçevede çevre sorunlarını çözmek adına mevzuatta ve kurumsal yapıda ilerlemeler kaydedildiği, Ulusal Çevre Stratejisi ve Eylem Planı (UÇEP)'nın hazırlandığı, temiz bir çevreye yönelik toplumsal duyarlılığın arttığı belirtilmiştir (SBYKP, 2001: 1-19).

$\mathrm{Bu}$ olumlu gelişmelere rağmen sürdürülebilir kalkınma yaklaşımı doğrultusunda, insan sağlığı ve doğal dengeyi koruyarak sürekli ve ekonomik kalkınmaya imkan verecek, doğal kaynakların yönetimini sağlayacak, gelecek kuşaklara daha sağlılı doğal, fiziki ve sosyal çevre bırakacak yönde bir gelişmenin kaydedilemediği ve çevre politikalarının ekonomik ve sosyal politikalara entegrasyonunun sağlanamadığı da ifade edilmiştir.

Sanayinin çevreye uyumlu üretim yapması, ithalatın çevreye zarar vermemesi, bölge planları çerçevesinde çevre kirliliğinin ele alınması, GAP ve DOKAP gibi bölgesel kalkınma projeleri kapsamında çevre kalitesinin arttırılmasının göz önünde bulundurulması gerektiği belirtilirken, göçlerin ve hızlı kentleşmenin çevre kirliliğinin artmasına yol açtığı da yine bu kapsamda ifade edilmiştir. Çevresel sorunların önemli bir maliyet unsuru olduğu bu nedenle çevreyi en az düzeyde tahrip edecek sürdürülebilir bir kalkınma anlayışına tekrar tekrar vurgu yapılmıştır (SBYKP, 2001: 20-141).

Sekizinci Planın çevre ile ilgili olan kısmının planlanması aşamasında UÇEP (Ulusal Çevre Stratejisi Eylem Planı)'in faaliyetlerinin uygulanmasının esas alındığı görülmektedir. Bu kapsamda konuyla ilgili kurum ve kuruluşların koordinasyonuna değinilerek UÇEP'in güncelleştirilip yasal bir çerçeveye kavuşturulacağı belirtilmiştir. Çevresel Etki Değerlendirme (ÇED) Yönetmeliğinin uygulama sürecinde istenen başarıya ulaşılamadığı ve sürecin daha etkili olabilmesi için düzenlemelerin yapılacağı ifade edilmiştir (SBYKP, 2001: 187-188).

$A B$ 'ye uyum, bölgesel hedef ve politikalar kapsamında çevre ile ilgili düzenlemelerin yapılmasına birçok yerde vurgu yapılmış ve çevre müktesebatı başlığında yer alan $174 \mathrm{AB}$ mevzuatının \%98'inin incelendiği belirtilmiştir. Altıncı Çevre Eylem Programı'nda da belirtilen sürdürülebilir kalkınma gibi eylem programlarının önceliklerine Sekizinci Kalkınma Planı'nda da yer verilmiştir. $\mathrm{Bu}$ açıdan $\mathrm{AB}$ politikalarına da uyumlu bir plan olduğu ifade edilebilir.

Sekizinci Plan Dönemindeki Türkiye-AB ilişkileri, bir dizi önemli gelişmeye sahne olmuştur. Kopenhag Avrupa Konseyi Zirvesi'nde, Türkiye'nin Kopenhag siyasi kriterlerini karşıladığı kararını alması halinde, müzakerelerin gecikmeden başlatılacağının belirtilmesi, Türkiye Büyük Millet Meclisi'nde “AB Uyum Komisyonu”'nun kurulması, AB'nin Türkiye ile tam üyelik müzakerelerinin başlaması bu önemli gelişmelerden birkaçını oluşturmaktadır.

\subsection{Dokuzuncu Beş Yıllık Kalkınma Planı (2007-2013)}

"İstikrar içinde büyüyen, gelirini daha adil paylaşan, küresel ölçekte rekabet gücüne sahip, bilgi toplumuna dönüşen ve $\mathrm{AB}$ 'ye üyelik için uyum sürecini tamamlamış bir Türkiye" vizyonu ile yayımlanan planda çevre başlığ ilk olarak Ekonomik Ve Sosyal Gelişme Eksenleri içerisinde yer alan Rekabet Gücünün Arttırılması başlığı altındaki Çevrenin Korunması ve Kentsel Altyapının Geliştirilmesi bölümünde yer alınmıştır. Planda çevre sorunları ve çözümlerine ilişkin politikalar, diğer planlarda da olduğu gibi sürdürülebilir kalkınma ile beraber ele alınmıştır.

Hızlı nüfus artışı ve sanayileşme sürecinin doğal kaynakların sürdürülebilirliğini, üretim sürecini ve çevrenin korunmasını tehdit ettiği belirtilen planda, Genetik Olarak Değiştirilmiş Organizmalar (GDO) ve biyoteknoloji ürünlerinin kullanımı ve dolaşımı konusunda standartların oluşturulması ihtiyacı vurgulanmıştır. Gelecek kuşakların ihtiyaçlarının gözetilmesi, 
kaynaklardan herkesin adil olarak faydalanmasının sağlanması, ülkemizin sahip olduğu biyolojik çeşitliliğin ve genetik kaynakların korunması ve ekonomik değere dönüştürülmesi, çevreye duyarlı sistemlerin geliştirilmesi, atık yönetiminin iyileştirilmesi ve çevre bilincinin geliştirilmesine yönelik eğitim ve kamuoyu bilgilendirme çalışmalarının yapılması planda yer verilen diğer önemli konulardır (DBYKP, 2007: 28-29).

$\mathrm{Bu}$ çerçevede Dokuzuncu Planın, Yedinci Eylem Programında temel ve kolaylaştırıcı hedeflerde belirtilen Doğal Sermaye, Kaynak Verimli Ekonomi, Sağlıklı Çevre ve İnsan, Artan Bilgi, Güvenli Yatırımlar ve Gelişmiş Uygulamalar ana başlıklarına uyumlu bir plan olduğu görülmektedir.

AB'ye uyum kapsamında bir başka uyumlu adım olarak çevre standartları ve yönetimini belirleyen hukuki düzenlemelerin güncelleştirilmesinde ülke koşulları ve kamu yönetiminin de etkinliğinin gözetilmesi olduğu söylenebilir. Ayrıca planda belirtilen kirleten ve kullanan öder ilkelerini dikkate alan araçların etkili biçimde kullanılması gerek eylem programlarının genelinde belirtilen ilkelere gerekse $\mathrm{AB}$ çevre politikalarına uygun bir yaklaşım olarak görülmektedir (DBYKP, 2007: 73-74).

Ülkemiz şartları çerçevesinde ilgili tarafların katılımıyla sera gazının azaltılmasına yönelik politika ve tedbirlerin ortaya konulacağı bir Ulusal Eylem Planının hazırlanması ve BM İklim Değişikliği Çerçeve Sözleşmesine ilişkin yükümlülüklerin yerine getirilmesinin belirtilmesi planın uluslararası alandaki gelişmelere de uygun olarak hazırlandığının göstergesidir (DBYKP, 2007: 73-75).

Plan dahilindeki yıllarda Türkiye-AB ilişkilerinde konu itibariyle öne çıkan unsur 21 Aralık 2009 tarihinde çevre faslında fiili müzakerelerin açılmasıdır. Çevre başlığının haricinde açılan müzakere başlıkları vergilendirme, sermayenin serbest dolaşımı, işletmeler ve sanayi politikaları ve gıda güvenliği gibi konular üzerine olmuştur.

\subsection{Onuncu Beș Yıllık Kalkınma Planı (2014-2018)}

Günümüzde yürürlükte olan onuncu planda çevre konusu, ikinci bölümde yer alan Planın Hedef Ve Politikaları başlığı altında Yaşanabilir Mekânlar, Sürdürülebilir Çevre alt başlığında çevreye duyarlı yaklaşımların sosyal ve ekonomik faydalarının artırılması, insanların şehirlerde ve kırsal alanlarda yaşam kalitesinin sürdürülebilir olarak yükseltilmesine yönelik hedef ve politikalar çerçevesinde ele alınmıştır. Çevre sorunlarının ve çözüm arayışlarının sürdürülebilir kalkınma çerçevesinde ele alınması onuncu planda da devam etmektedir.

$\mathrm{Bu}$ çerçevede sürdürülebilir kalkınma hedeflerine ulaşmak için uluslararası gelişmelerin de etkisiyle, üretim sektörlerinde temiz üretim ve eko-verimlilik ile hem çevrenin korunması hem de rekabetçiliğin artırılmasını hedefleyen "yeşil büyüme" kavramının önem kazandığı belirtilmiştir. Türkiye'nin uluslararası düzeyde çevre sorunlarının çözümüne yönelik olarak ülke gerçeklerini gözeten bir anlayışla, "ortak fakat farklılaştırılmış sorumluluklar" ve "göreceli kapasiteler" ilkeleri çerçevesinde katkı verdiği ifade edilmiştir (OBYKP, 2013: 13).

Planda Türkiye'nin çevre üzerinde oluşan baskıyı, kirliliğin önlenmesi çalışmaları, biyolojik çeşitlilik ve doğal kaynakların korunması ile sürdürülebilir kullanımına öncelik veren politikaları benimseyerek azaltacağı belirtilmiştir. Bu kapsamda plan içerisinde yer alan turizm, altyapı, enerji, lojistik ve ulaştırma, sanayi gibi hemen hemen bütün alt başlıklarda çevrenin korunmasını içeren ya da çevrenin ön planda tutulmasını öngören yaklaşımlara yer verildiği görülmüştür.

Yaşanabilir mekânların en önemli boyutlarından birinin çevresel kalitenin korunması, gelecek nesillerin refah ve mutluluğunu azaltmayacak bir kalkınma ve mekânsal gelişme yaklaşımının benimsenmesi olduğu belirtilmiştir. Bu yaklaşım aynı zamanda Türkiye'nin 
çevresel sorunların çözümü için yıllar içerisinde geliştirdiği politikaların son halini göstermektedir (OBYKP, 2013: 118).

Yukarıda yer verilen önceliklere ve politikalara bakıldığı zaman Onuncu Kalkınma Planının gerek Dokuzuncu Kalkınma Planı'nda görülen önceliklerle gerekse Yedinci Eylem Planı'nda belirtilen; güvenli yatırımlar, kaynak verimli ekonomi ve doğal sermaye gibi önceliklerle uyumlu olduğu görülmektedir.

Plan içeriğinde iki önemli husus dikkat çekmektedir. Bunlardan birincisi çevre ile ilgili olarak diğer planların aksine AB'ye atıf yapılan hiçbir doğrudan ibarenin olmayışıdır. İkincisi ise yine bu çerçevede Dokuzuncu Kalkınma Planına yapılan sürekli atıflar ve karşılaştırmalardır. Türkiye- $\mathrm{AB}$ ilişkilerinde de plan döneminde gerçekleşen kayda değer bir gelişme bulunmamaktadır.

\section{5. ÇEVRE POLITIKALARININ EKONOMIKK GÖSTERGELER ÇERÇEVESINDE DEĞERLENDİRILMESİ}

Çevre politikalarının AB ve Türkiye'de gelişme süreçlerinin Çevresel Eylem Planları ve Beş Yıllık Kalkınma Planları çerçevesinde değerlendirilmesinin yanında bu yazılı belgelerin uygulanması için ne ölçüde kaynak aktarıldığını görmek ülkelerin bu konudaki hassasiyetini de ortaya koymaktadır.

Çalışmada AB'nin kurucu ülkelerinden üç tanesi olan Fransa, Almanya ve Belçika ve birliğe en son katılan üç ülke olan Romanya, Bulgaristan ve Hirvatistan örnek ülkeler olarak seçilmiştir. Türkiye'nin bu ülkeler ile karşılaştırılmasını içeren bu bölümde AB üyesi olan 28 ülkenin toplam harcamalarına da yer verilmiştir. Bu ülkelerin 2001-2013 yılları arasındaki, çevre koruma harcamalarının kişi başına ve GSYİH içindeki oranı sadece kamu açısından, çevre koruma harcamaları ve çevre yatırım harcamaları hem kamu hem de özel sektör açısından incelenmiştir.

İnceleme, kirliliğin azaltılması, önlenmesi ve giderilmesine ya da çevrenin bozulmasına etki eden bütün doğrudan aktiviteleri içeren çevresel koruma tanımı içerisinde yer almaktadır. $\mathrm{Bu}$ çerçevede çevresel harcama verileri birçok sektörün mevcut harcamalarını ve farklı yatırımlarını içermektedir.

Kamu harcamaları ve yatırımları, merkezi, bölgesel ve yerel yönetimler arasındaki net transferleri ifade ederken, özel sektör harcamaları ve yatırımları imalat sanayi, tarım, balıkçılık, ormancılık, madencilik ve taş ocakçılığı, elektrik, gaz, buhar ve iklimlendirme üretimi ve dağıtımı; su toplama, arıtma, tedarik ve diğer kategorileri kapsamaktadır.

Çevre koruma harcamaları içinde, kirliliğin doğrudan önlenmesi, azaltılması ve ortadan kaldırılmasını veya üretim süreçleri ya da mal ve hizmetlerin tüketiminden kaynaklanan rahatsızlıkların ortadan kaldırılmasını amaçlayan harcamalar yer alırken, çevreye faydalı olmasına rağmen, teknik ihtiyaçları, sağlık ya da güvenlik gereksinimlerini karşılamaya yönelik yapılan aktiviteler hariç tutulmuştur.

Yatırım harcamaları ise bir yıl içerisinde çevreyi koruma amacıyla kullanılan makine, teçhizat ve arazi için satın alınan ya da kendi hesabına üretim için yapılan harcamaları ifade etmektedir.

\subsection{Kamu Sektörü Çevre Harcamaları ve Yatırımlarının Karşılaştırılması}

Tablo 1'de 2001-2013 yılları arasındaki çevrenin korumasına yönelik kamu harcamaları verilmiştir. Tabloya göre Türkiye, harcamaların yıllar içerisinde sürekli arttığı tek ülkedir. 
Fransa'nın çevre koruma harcamaları AB'nin toplam çevre harcamalarının yaklaşık \%13'ünü oluştururken, Birliğe yeni katılan ülkelerin bu kapsamdaki kamusal harcamaları çok düşük seviyelerdedir.

Tablo 2: 2001-2013 Çevrenin Korumasına Yönelik Kamu Harcamaları (Milyon Avro)

\begin{tabular}{|l|l|l|l|l|l|l|l|l|}
\hline Zaman/Ülke & AB-28 & Belçika & Fransa & Almanya & Bulgaristan & Hırvatistan & Romanya & Türkiye \\
\hline $\mathbf{2 0 0 1}$ & $62.789,13$ & $1.474,22$ & $8.301,89$ & 9.170 & 70,05 & 15,09 & 58,11 & 171,33 \\
\hline $\mathbf{2 0 0 2}$ & $62.856,75$ & $1.552,95$ & $8.929,89$ & 8.930 & 59,29 & 34,52 & 94,99 & 256,04 \\
\hline $\mathbf{2 0 0 3}$ & $62.270,65$ & $1.415,81$ & $8.673,91$ & 8.760 & 54,73 & - & 69,38 & $1.018,35$ \\
\hline $\mathbf{2 0 0 4}$ & $65.586,06$ & $1.717,71$ & $8.891,07$ & 8.420 & 68,91 & - & 134,19 & $1.246,29$ \\
\hline $\mathbf{2 0 0 5}$ & $74.258,65$ & $1.599,69$ & $9.650,28$ & 8.140 & 86,88 & 23,96 & 186 & $1.545,73$ \\
\hline $\mathbf{2 0 0 6}$ & $81.154,77$ & $1.812,25$ & $9.827,16$ & 8.220 & 104,49 & 31,04 & 527,94 & $1.701,79$ \\
\hline $\mathbf{2 0 0 7}$ & $83.932,02$ & $1.831,75$ & $10.355,52$ & 8.020 & 161,03 & 154,79 & 716,81 & $2.022,45$ \\
\hline $\mathbf{2 0 0 8}$ & $84.133,57$ & $1.954,97$ & $11.023,96$ & 8.070 & 209,11 & 10,13 & 804,94 & $2.063,98$ \\
\hline $\mathbf{2 0 0 9}$ & $88.446,73$ & $2.066,46$ & $11.398,01$ & 8.110 & 223,73 & 11,05 & 699,08 & $2.208,28$ \\
\hline $\mathbf{2 0 1 0}$ & $86.427,57$ & $2.152,98$ & $11.570,35$ & 8.270 & 183,66 & 33,09 & $1.012,88$ & $2.490,67$ \\
\hline $\mathbf{2 0 1 1}$ & $86.510,92$ & $2.589,55$ & $11.646,07$ & - & 231,41 & 142,76 & $1.254,95$ & - \\
\hline $\mathbf{2 0 1 2}$ & $87.495,34$ & $2.355,53$ & $12.065,35$ & - & 293,43 & 113,68 & 787,85 & $2.625,14$ \\
\hline $\mathbf{2 0 1 3}$ & $87.346,45$ & - & - & - & 425,21 & 139,5 & 647,62 & - \\
\hline
\end{tabular}

Kaynak: (Eurostat, 2016).

Türkiye'nin özellikle 2001-2005 yılları arasında, Sekizinci Kalkınma Planı'na denk gelen süreç içerisinde 2002 yılından 2003 yılına neredeyse dört katına yakın bir harcama artışı gerçekleştirdiği görülmektedir. Bu sıçrayışı zaman içerisinde istikrarlı bir şekilde arttırmış, kriz dönemlerinde bile bir azalış gözlemlenmemiştir. Örnekte yer alan diğer AB ülkeleri ile olan durumuna bakıldığı zaman son yıllarda Belçika'dan daha fazla harcama yaptığı görülse de Fransa ve Almanya ile aralarında büyük harcama farklılıkları mevcuttur. Birliğin yeni üyeleri ise Türkiye'nin 2003 yılında yaptığı harcama miktarına bile yaklaşamamışlardır. 2013 yılında Hırvatistan, Türkiye'nin 2001 yılındaki harcama seviyesinden bile daha düşük bir harcama gerçekleştirmiştir. Sonuç olarak Türkiye'nin Fransa ve Almanya dışında diğer ülkelere göre daha fazla çevrenin korunmasına yönelik kamu harcamaları yaptığı ortadadır. 
Tablo 3: 2001-2013 Çevrenin Korumasına Yönelik Kamu Harcamalarının GSYİH İçindeki Payı (\%)

\begin{tabular}{|l|l|l|l|l|l|l|l|l|}
\hline Zaman/Ülke & AB-28 & Belçika & Fransa & Almanya & Bulgaristan & Hırvatistan & Romanya & Türkiye \\
\hline $\mathbf{2 0 0 1}$ & 0,65 & 0,57 & 0,56 & 0,44 & 0,45 & 0,06 & 0,13 & 0,08 \\
\hline $\mathbf{2 0 0 2}$ & 0,63 & 0,58 & 0,58 & 0,42 & 0,35 & 0,12 & 0,2 & 0,11 \\
\hline $\mathbf{2 0 0 3}$ & 0,61 & 0,51 & 0,55 & 0,41 & 0,3 & - & 0,13 & 0,38 \\
\hline $\mathbf{2 0 0 4}$ & 0,62 & 0,59 & 0,54 & 0,38 & 0,34 & - & 0,22 & 0,4 \\
\hline $\mathbf{2 0 0 5}$ & 0,67 & 0,53 & 0,56 & 0,37 & 0,37 & 0,07 & 0,23 & 0,4 \\
\hline $\mathbf{2 0 0 6}$ & 0,69 & 0,57 & 0,55 & 0,36 & 0,39 & 0,08 & 0,54 & 0,41 \\
\hline $\mathbf{2 0 0 7}$ & 0,67 & 0,55 & 0,55 & 0,33 & 0,52 & 0,36 & 0,57 & 0,43 \\
\hline $\mathbf{2 0 0 8}$ & 0,67 & 0,56 & 0,57 & 0,33 & 0,59 & 0,02 & 0,58 & 0,41 \\
\hline $\mathbf{2 0 0 9}$ & 0,75 & 0,61 & 0,6 & 0,34 & 0,64 & 0,02 & 0,59 & 0,5 \\
\hline $\mathbf{2 0 1 0}$ & 0,7 & 0,61 & 0,6 & 0,33 & 0,51 & 0,07 & 0,81 & 0,45 \\
\hline $\mathbf{2 0 1 1}$ & 0,68 & 0,7 & 0,58 & - & 0,6 & 0,32 & 0,95 & - \\
\hline $\mathbf{2 0 1 2}$ & 0,68 & 0,63 & 0,59 & - & 0,73 & 0,26 & 0,6 & 0,43 \\
\hline $\mathbf{2 0 1 3}$ & 0,67 & - & - & - & 1,06 & 0,32 & 0,46 & - \\
\hline$K a y n$
\end{tabular}

Kaynak: (Eurostat, 2016).

Tablo 2'de çevrenin korumasına yönelik kamu harcamalarının GSYİH içindeki payı görülmektedir. 2010 yılına baktığımız zaman $\mathrm{AB}$ ortalamasının \% 0,7 olduğu ve örnekteki birçok ülkenin bu ortalamaya sahip olmadığı göze çarpmaktadır. Fransa ve Almanya gibi yüksek miktarda harcamaya sahip ülkelerin çevre koruma harcamalarının GSYIH içindeki payının AB ortalamasından düşük olduğu hatta Almanya'nın Türkiye ve Romanya gibi ülkelerin gerisinde kaldığı görülmektedir. Romanya, söz konusu ülkeler arasında hem en yüksek orana sahip hem de $\mathrm{AB}$ ortalamasının üzerindeki tek ülke olmuştur.

Tablo 4: 2001-2013 Çevrenin Korumasına Yönelik Kamu Harcamaları (Kişi Başı Avro)

\begin{tabular}{|l|l|l|l|l|l|l|l|l|}
\hline Zaman/Ülke & AB-28 & Belçika & Fransa & Almanya & Bulgaristan & Hırvatistan & Romanya & Türkiye \\
\hline $\mathbf{2 0 0 1}$ & 128,63 & 143,64 & 136,14 & 111,48 & 8,6 & 3,51 & 2,59 & 2,52 \\
\hline $\mathbf{2 0 0 2}$ & 128,52 & 150,63 & 145,38 & 108,32 & 7,51 & 8,02 & 4,35 & 3,72 \\
\hline $\mathbf{2 0 0 3}$ & 126,87 & 136,72 & 140,21 & 106,13 & 6,98 & - & 3,21 & 14,6 \\
\hline $\mathbf{2 0 0 4}$ & 133,11 & 165,22 & 142,73 & 102,02 & 8,83 & - & 6,24 & 17,63 \\
\hline $\mathbf{2 0 0 5}$ & 150,09 & 153,14 & 153,73 & 98,67 & 11,19 & 5,56 & 8,7 & 21,59 \\
\hline $\mathbf{2 0 0 6}$ & 163,41 & 172,41 & 155,42 & 99,71 & 13,54 & 7,2 & 24,84 & 23,47 \\
\hline $\mathbf{2 0 0 7}$ & 168,4 & 173,06 & 162,71 & 97,43 & 21,26 & 35,89 & 33,92 & 29,02 \\
\hline $\mathbf{2 0 0 8}$ & 168,13 & 183,28 & 172,23 & 98,15 & 27,82 & 2,35 & 39,01 & 29,24 \\
\hline $\mathbf{2 0 0 9}$ & 176,12 & 192,17 & 177,12 & 98,9 & 29,96 & 2,56 & 34,2 & 30,88 \\
\hline $\mathbf{2 0 1 0}$ & 171,69 & 198,62 & 178,94 & 101,1 & 24,75 & 7,69 & 49,91 & 34,33 \\
\hline $\mathbf{2 0 1 1}$ & 171,32 & 235,4 & 179,23 & - & 31,4 & 33,28 & 62,13 & - \\
\hline $\mathbf{2 0 1 2}$ & 172,88 & 212,31 & 184,8 & - & 40,05 & 26,59 & 39,2 & 35,13 \\
\hline $\mathbf{2 0 1 3}$ & 172,23 & - & - & - & 58,37 & 32,73 & 32,35 & - \\
\hline
\end{tabular}

Kaynak: (Eurostat, 2016). 
Çevrenin korumasına yönelik kişi başına düşen kamu harcamalarının yer aldığı Tablo 3'de 2010 yılı için Belçika ve Fransa AB ortalamasının üzerinde seyrederken, Almanya, Bulgaristan, Romanya ile büyük artış ve azalışlara sahip düzensiz bir seyir izleyen Hırvatistan ve 2001 yılından itibaren sürekli artan bir trende sahip olan Türkiye, AB ortalamasının çok altında yer almıştır.

Tablo 5: 2001-2013 Kamunun Toplam Çevre Yatırımları- Milyon Avro

\begin{tabular}{|l|l|l|l|l|l|l|l|l|}
\hline Zaman/Ülke & AB-28 & Belçika & Fransa & Almanya & Bulgaristan & Hirvatistan & Romanya & Türkiye \\
\hline $\mathbf{2 0 0 1}$ & $13.031,49$ & 528,34 & $1.701,45$ & 2.730 & 24,43 & 7,43 & 13,31 & 24,77 \\
\hline $\mathbf{2 0 0 2}$ & $13.007,98$ & 518,06 & $1.695,07$ & 2.650 & 32,33 & 12,11 & 13,69 & 142,42 \\
\hline $\mathbf{2 0 0 3}$ & $13.442,26$ & 482,3 & $1.802,21$ & 2.550 & 26,41 & 18,99 & 18,43 & 347,99 \\
\hline $\mathbf{2 0 0 4}$ & $14.571,7$ & 436,35 & $1.906,47$ & 2.390 & 33,4 & 3,71 & 71,32 & 357,26 \\
\hline $\mathbf{2 0 0 5}$ & $15.622,85$ & 274 & $2.382,63$ & 2.140 & 44,36 & 23,95 & 82,38 & 480,41 \\
\hline $\mathbf{2 0 0 6}$ & $16.605,93$ & 399,1 & $1.105,27$ & 2.100 & 50,65 & 20,32 & 128,11 & 524,27 \\
\hline $\mathbf{2 0 0 7}$ & $17.024,04$ & 288,4 & $1.172,79$ & 2.010 & 74,3 & 149,71 & 389,13 & 524,27 \\
\hline $\mathbf{2 0 0 8}$ & $17.289,44$ & 284,1 & $1.290,27$ & 2.020 & 108,43 & 1,82 & 444,11 & 465,26 \\
\hline $\mathbf{2 0 0 9}$ & $16.959,85$ & 276,9 & $1.345,43$ & 2.040 & 105,65 & 3,03 & 358,07 & 351,96 \\
\hline $\mathbf{2 0 1 0}$ & $16.148,81$ & 121,1 & $1.357,99$ & 1.880 & 73,14 & 23,55 & 436,88 & 427,05 \\
\hline $\mathbf{2 0 1 1}$ & $16.955,84$ & 145,2 & $1.571,23$ & - & 73,46 & 115,43 & 594,98 & - \\
\hline $\mathbf{2 0 1 2}$ & $15.701,15$ & 223,4 & $1.685,69$ & - & 72,37 & 10,21 & 283,3 & 522,1 \\
\hline $\mathbf{2 0 1 3}$ & $16.437,05$ & - & - & - & 193,76 & 135,96 & 139,7 & - \\
\hline
\end{tabular}

Kaynak: (Eurostat, 2016).

Kamusal harcamalarda son olarak toplam çevre yatırımlarının yer aldığı Tablo 4'e baktığımızda Türkiye'nin 2012 yılı itibariyle kamusal olarak Hırvatistan, Bulgaristan ve Romanya gibi birliğe katılan son üç ülkeden ve birliğin kurucu ülkelerinden olan Belçika'ya göre daha fazla çevre yatırımı yaptığı görülmektedir. Türkiye'nin bu alanda yaptığı yatırımlar AB'nin yaptığı yatırımların \%3.3'ünü oluşturmaktadır. Sekizinci Beş Yıllık Kalkınma Planı döneminde söz konusu yatırımlarda ciddi bir sıçrama görülmektedir.

Türkiye açısından kamusal harcamalara genel olarak baktığımızda ele alınan her değişken için farklı sonuçlara ulaşıldığı görülmektedir. Rakamsal olarak Türkiye'nin Birliğe son olarak katılan üç ülkeden daha yüksek bir harcama miktarına sahip olduğu, harcamaların GSYİH içindeki yüzdesi bakımından $\mathrm{AB}$ ortalamasının altında yer alırken Almanya gibi güçlü bir Birlik ülkesine göre daha fazla harcama oranına ulaştığı, kişi başı harcama bakımından ise Birlik ortalamasının altında olmasına rağmen sürekli artan bir trende sahip olduğu görülmektedir. Çevre yatırımları konusunda da hem AB'nin geneline göre hem de son olarak Birliğe katılan üç ülkeye göre iyi bir seyir izlediği söylenebilir. 


\section{2. Özel sektör Çevre Harcama ve Yatırımlarının Karşılaştırılması}

Tablo 6: 2001-2013 Özel Sektörün Çevre Koruma Harcamaları (Milyon Avro)

\begin{tabular}{|l|l|l|l|l|l|l|l|}
\hline Zaman/Ülke & Belçika & Fransa & Almanya & Bulgaristan & Hırvatistan & Romanya & Türkiye \\
\hline $\mathbf{2 0 0 1}$ & $2.353,16$ & $11.480,43$ & 11.300 & 247,6 & 68,6 & 387,43 & - \\
\hline $\mathbf{2 0 0 2}$ & $2.535,85$ & $11.932,98$ & 10.800 & 183,86 & 103,22 & 628,87 & - \\
\hline $\mathbf{2 0 0 3}$ & $2.617,95$ & $12.217,94$ & 10.620 & 238,85 & 123,29 & 379,79 & - \\
\hline $\mathbf{2 0 0 4}$ & $2.506,45$ & $12.827,4$ & 10.710 & 267,2 & 255,85 & 609,86 & - \\
\hline $\mathbf{2 0 0 5}$ & $2.015,39$ & $13.463,88$ & 10.160 & 181,33 & 265,85 & 529,18 & - \\
\hline $\mathbf{2 0 0 6}$ & $1.180,99$ & $14.513,53$ & 10.230 & 365,47 & 339,13 & 697,94 & - \\
\hline $\mathbf{2 0 0 7}$ & $1.247,2$ & $14.961,42$ & 11.320 & 341,63 & 387,22 & 822,73 & 438,22 \\
\hline $\mathbf{2 0 0 8}$ & $1.596,67$ & $15.398,62$ & 11.960 & 434,38 & 429,63 & $1.226,45$ & 455,87 \\
\hline $\mathbf{2 0 0 9}$ & 914,77 & $15.717,45$ & 11.770 & 313,19 & 414,52 & 926,81 & 537,49 \\
\hline $\mathbf{2 0 1 0}$ & $1.382,64$ & $15.989,75$ & 12.560 & 333,69 & 418,52 & $1.075,48$ & 676,34 \\
\hline $\mathbf{2 0 1 1}$ & $1.516,06$ & $16.527,02$ & - & 296,66 & 402,19 & $1.130,06$ & - \\
\hline $\mathbf{2 0 1 2}$ & $1.700,16$ & $17.585,25$ & - & 313,48 & 267,31 & $1.581,97$ & - \\
\hline $\mathbf{2 0 1 3}$ & - & - & - & 385,6 & 267,2 & $1.782,09$ & - \\
\hline
\end{tabular}

Kaynak: (Eurostat, 2016).

Özel sektör harcamaları kamusal incelemeden farklı bir tablo ortaya koymaktadır. Tablo 5'de verilen özel sektör çevre koruma harcamalarına baktığımız zaman Fransa, Almanya, Romanya ve Hırvatistan'ın özel sektör çevre koruma harcamalarının kamusal harcamalarına göre çok daha yüksek olduğu görülmektedir. Bulgaristan ve Belçika daha dalgalı bir seyir izlerken Türkiye kamusal harcamalarda gösterdiği başarılı performansı özel sektör harcamalarında gösterememiştir. Türkiye, incelenen ülkeler arasında özel sektör çevre koruma harcaması verilerinin en çok bilinmediği ülke olurken 2012 y1lı verisi için Eurostat tarafından gizli ibaresi konulmuştur.

Tabloda öne çıkan bir diğer unsur 2009 yılında küresel kriz sonrasında Türkiye ve Fransa dışındaki bütün ülkelerin harcamalarının azalmış olmasıdır. 2010 yılına baktığımız zaman Fransa ve Almanya'nın diğer ülkelere göre çok büyük oranda harcamalar yaptığı Türkiye'nin ise Bulgaristan ve Hırvatistan'a göre daha yüksek harcama yapmasına karşılık Romanya'nın yaklaşık yarısı kadar harcama yaptığı görülmektedir. 
Tablo 7: 2001-2013 Özel Sektörün Toplam Çevre Yatırımları (Milyon Avro)

\begin{tabular}{|l|l|l|l|l|l|l|l|}
\hline Zaman/Ülke & Belçika & Fransa & Almanya & Bulgaristan & Hırvatistan & Romanya & Türkiye \\
\hline 2001 & 469,93 & $2.083,07$ & 1.580 & 130,69 & 47,77 & 181,25 & - \\
\hline 2002 & 256,66 & $1.957,22$ & 1.650 & 80,73 & 57,21 & 239,99 & - \\
\hline 2003 & 261,97 & $1.751,96$ & 1.430 & 113,84 & 61,53 & 190,4 & - \\
\hline 2004 & 174,05 & $1.879,16$ & 1.580 & 132,64 & 139,58 & 242,88 & - \\
\hline 2005 & 230,33 & 2.252 & 1.410 & 92,05 & 149,34 & 225,41 & - \\
\hline 2006 & 189,57 & $2.857,09$ & 1.760 & 228,81 & 195,79 & 319,42 & - \\
\hline 2007 & 199,8 & $2.650,89$ & 2.780 & 186,28 & 218,39 & 398,76 & 138,42 \\
\hline 2008 & 354,06 & $2.982,54$ & 3.490 & 204,19 & 290,55 & 421,03 & 136,31 \\
\hline 2009 & 246,24 & $2.856,45$ & 3.070 & 149,73 & 258,88 & 418,2 & 56,57 \\
\hline 2010 & 356,04 & $2.716,06$ & 3.320 & 176,58 & 270,89 & 437,66 & 71,6 \\
\hline 2011 & 390,21 & $2.633,89$ & - & 127,68 & 230,13 & 330,36 & - \\
\hline 2012 & 357,66 & $2.854,62$ & - & 113,42 & 115,45 & 527,71 & - \\
\hline 2013 & - & - & - & 144,06 & 113,74 & 648,23 & - \\
\hline
\end{tabular}

Kaynak: (Eurostat, 2016).

Özel sektörün çevre yatırımlarının yer aldığı Tablo 6'da 2009 yılında küresel kriz sonrası bütün ülkelerin harcamalarında küçük azalışlar görülmektedir. Bu azalış Türkiye'de diğer ülkelere göre çok daha büyük oranda gerçekleşmiştir. Türkiye için bir başka öne çıkan unsur yatırımlar ile ilgili verilerin diğer ülkelere göre daha az oluşudur. Rakamsal olarak da diğer ülkelerin çok daha altında yer alan Türkiye'nin AB'ye göre çok düşük yatırım düzeylerine sahip olduğu görülmektedir.

Türkiye'nin bu alandaki yatırım miktarı 2010 yılına göre Birliğin güçlü ülkeleri olan Almanya'nın ve Fransa'nın sırasıyla \% 2,1'i ve \% 2,6'sı civarındayken, Birliğe son katılan üç ülke olan Bulgaristan, Hirvatistan ve Romanya'nın sirasiyla \% 40,3, \%26,2 ve \%16,2'si kadardır. Almanya ve Fransa incelenen bütün ülkeler arasında özel sektörü en fazla yatırım yapan ülke olarak öne çıkmaktadır

Kamu ve özel sektör harcamalarını beraber yorumladığımız zaman Türkiye'deki çevre koruma konusundaki harcamaların çoğunun devlet tarafindan yapıldığı ortaya çıkmaktadır. AB'de ise harcamalar Fransa ve Almanya gibi ülkelerde hem devlet hem özel sektörce yüksek rakamlarda yapılırken, Birliğin son üyelerinden Romanya ve Hırvatistan'da özel sektör harcamalarının kamu harcamalarına göre daha fazla olduğu görülmektedir.

Yatırımlar açısından baktığımızda Türkiye'nin kamu yatırımlarının Birliğin son üç üyesine göre daha fazla olduğu fakat özel sektör yatırımlarında Türkiye'nin sinıfta kaldığ gözlemlenmiştir. AB'de çevresel yatırımların büyük çoğunluğu özel sektör yatırımlarından oluşurken, Türkiye'de çevresel yatırımlar çoğunlukla kamu yatırımlardan oluşmaktadır.

Sonuç olarak incelenen $\mathrm{AB}$ ülkelerinin çevre konusundaki yatırım ve harcamalarının kamudan ziyade özel sektör ağırlıklı olduğu görülmektedir. Türkiye'de ise kamu yatırım ve harcamaların özel sektöre göre daha fazla olduğu gözlemlenmiştir. Türkiye Kamu yatırım ve harcamaları bakımından özellikle birliğin son üç üyesi ile kıyaslandığında iyi bir seyir izlemiştir. Ancak özel sektör yatırım ve harcamalarında aynı başarıyı gösterememiştir. 


\section{SONUÇ}

AB'nin 1970'li yıllarda "Roma Kulübü" ile başlayan ve Birinci Çevre Eylem Planı ile devam eden sürecine Türkiye Üçüncü Beş Yıllık Kalkınma Planı ile entegre olmaya başlamıştır. Üçüncü plandan sonraki her plan döneminde yapılması hedeflenen politikaların çoğunun $\mathrm{AB}$ politikalarıyla uyumlu olduğu görülmüştür. Hatta Altıncı Plan'da yer alan sürdürülebilirlik kavramı ile Birliğe göre öncü adımlar da atmıştır.

Türkiye'nin bütün çevresel planlamaları çevreyi koruma önceliğinde değil kalkınmayı sağlama önceliğinde yapılmıştır. Kalkınma planlarının içerisinde açıça ifade edilen bu durum AB'nin çevre koruma yaklaşımından bu yönüyle farklılaşmaktadır. Bu farklılaşmaya rağmen Türkiye'nin çevre politikasının neredeyse tamamı AB program ve politikaları çerçevesinde şekillenmiştir.

Sekizinci Kalkınma Planıyla beraber çevre sorunlarına yaklaşımda daha ciddi adımların atıldığı görülmüştür. Bu adımlar gerek planda yer verilen politikalarda gerekse çevresel yatırım ve harcamalarda kendini göstermiştir. Yatırımların ve harcamaların çoğu kamu ağırlıklı yatırımlardan oluşmaktadır ve bu açıdan $\mathrm{AB}$ ile kıyaslandığında olumlu bir gelişim sergilemiştir. Özel sektör yatırım ve harcamaları ise AB'nin çok gerisinde kalmıştır.

Türkiye, gelişmekte olan bir ülke olarak kalkınmaya öncelik vermesi, çevreyi kalkınmanın tamamlayıcı bir unsuru olarak görmesi, uygulanması güç olan ya da büyük kaynak aktarımı gerektiren politikalara yer vermesi ve bazı önceliklerin birbiri ile çelişmesi gibi nedenlerle çevre politikalarını oluştururken AB'ye bu kadar bağlı kalmasına rağmen uygulamada aynı başarıyı gösterememiştir.

Çevre yatırım ve harcamalarının büyük ölçüde kamu tarafından yapılması, Türkiye'nin belirlediği her politikayı başarıyla sonuçlandıramamasının bir diğer nedenidir. Büyük ölçüde kaynak aktarımı gerektiren bu yaklaşım, kalkınmaya öncelik verilmesi kapsamında özel sektöre çevre maliyetinin yansıtılmamasının bir sonucu olarak düşünülmektedir.

Türkiye'nin AB'ye uyum için mevzuatta yakaladığı başarıyı uygulamada da yakalayabilmesi için, $\mathrm{AB}$ genel politikaları çerçevesinde kendi içsel dinamiklerine uygun politikalar geliş̧irmelidir. Bu önceliklere sürdürülebilir kalkınmayı sekteye uğratmayacak özel sektör yatırım ve harcamalarını da içeren bütüncül politikalar da eklenmelidir. Aksi takdirde çevre konusunda başarıya ulaşılması kısa vadede mümkün gözükmemektedir.

\section{KAYNAKÇA}

AB, (2015). Avrupa Birliği Bakanlı̆̆ı. [Çevrim-içi: http://www.ab.gov.tr/index.php?p=92\&l=1], Erişim Tarihi: 14.05.2016.

AB, (2016). Avrupa Birliği Bakanlı̆̆l. .[Çevrim-içi: http://www.ab.gov.tr/index.php?p=112\&l=1], Erişim Tarihi: 15.06.2016.

ABYKP, (1990). Altıncı Beş Yıllık Kalkınma Planı. [Çevrim-içi: http://www.kalkinma.gov.tr/Pages/KalkinmaPlanlari.aspx], Erişim Tarihi: 15.06.2016.

Akbaş, G. ve Apar, A. (2010). Avrupa 2020 stratejisi: akıll, sürdürülebilir ve kapsayıcı büyüme için Avrupa stratejisi özet bilgi notu. T.C. Başbakanlık Avrupa Birliği Genel Sekreterliği Sosyal, Bölgesel ve Yenilikçi Politikalar Başkanlığı, Ankara.

Bayram, T. T., Altıkat, A. ve Torun, F.E. (2011). Avrupa Birliği ve Türkiye'de çevre politikaları. Iğdır Üniversitesi Fen Bilimleri Enstitüsü Dergisi, 1:1, 33-38.

BBYKP, (1963). Birinci Beş Yıllık Kalkınma Planı. [Çevrim-içi: http://www.kalkinma.gov.tr/Pages/KalkinmaPlanlari.aspx], Erişim Tarihi: 17.06.2016.

BBYKP, (1985). Beşinci Beş Ylllık Kalkınma Planı. http://www.kalkinma.gov.tr/Pages/KalkinmaPlanlari.aspx], Erişim Tarihi: 05.08.2016. 
Biyan, Ö. ve Gök, M. (2014). Çevre Politikaları Kapsamında Avrupa Birliği ve Türkiye'de Çevre Vergilerinin Uygulanış1: Karşılaştırmalı Bir Analiz. Hitit Üniversitesi Sosyal Bilimler Enstitüsü Dergisi, 7:2, 281-310.

Bozkurt, Y. (2010). Avrupa Birliği’ne uyum sürecinde Türkiye'de çevre politikalarının dönüşümü. Bursa: Ekin Yayınevi.

Bruyninckx, H. (2014). European Economic Area Newsletter, (Issue 2014/2, 16 June). European Environment Agency.

Budak, S. (2000). Avrupa Birliği ve Türk Çevre Politikası. İstanbul:Büke Yayınları Araştırma Dizisi 2000-6.

Burchell, J. \& Lightfoot, S. (2001). The Greening of the European Union?, London,:Sheffield Academic Press,, s.34.

Çapanoğlu, S.G. (2010). Geçmişten günümüze Lizbon Stratejisi ve 2020 için yeni bir vizyon ışı̆̆ında "AB 2020" stratejisi. İktisadi Kalkınma Vakfı Değerlendirme Notu 12.

Çokgezen, J. (2007). Avrupa Birliği çevre politikası ve Türkiye. Marmara Üniversitesi İ.I.B.F. Dergisi,23:2, 91-115.

Dağdemir, Ö. (2015). Çevre Sorunlarına Ekonomik Yaklaşımlar ve Optimal Politika Arayışları. 3. Basım, Ankara: Gazi Kitapevi.

DBYKP, (1979). Dördüncü Beş Ylllı Kalkınma Planı. http://www.kalkinma.gov.tr/Pages/KalkinmaPlanlari.aspx], Erişim Tarihi: 11.07.2016.

DBYKP, (2007). Dokuzuncu Beş Yıllık Kalkınma Planı. [Çevrim-içi: http://www.kalkinma.gov.tr/Pages/KalkinmaPlanlari.aspx], Erişim Tarihi: 21.11.2016.

Dinler, Z. (1998). Bölgesel İktisat. 5.basım, Bursa: Ekin Kitapevi Yayınları.

Dura, C. ve Atik, H. (2014). Avrupa Birliği Gümrük Birliği ve Türkiye. , 4. Baskı, İstanbul: Nobel Yayın Dağıtım.

Durmaz, B. (2004). Avrupa Birliğinde Çevre Politikası Alanında Muhtemel Müzakere Sürecine Yönelik Gerekli Hazırlıkların Örneklerle Çalışılması. Avrupa Birliği Genel Sekreterliği Sektörel Ve Bölgesel Politikalar Dairesi, Uzmanlık Tezi.

Duru, B. (2007). Avrupa Birliği çevre politikası. Erhan, Ç. ve Senemoğlu, D. (Der.), Avrupa Birliği Politikaları, Ankara: İmaj Yayınevi.

EC, (2016). European Commission. [Çevrim-içi: http://ec.europa.eu/environment/newprg/objectives.htm], Erişim Tarihi: 18.06.2016.

Erdoğdu, S. (2006). Küreselleşme Sürecinde Uluslararası Sendikacılık, 1. Baskı. Ankara: İmge Kitabevi.

EUROSTAT, (2016). European Community Statistical Office [Çevrim-içi: http://ec.europa.eu/eurostat], Erişim Tarihi: 22.07 .2016 .

FEAP, (1973). First Environmental Action Programme. Official journal of the European Communities, Volume 16, No C 112.

FEAP, (1987). Fourth Environmental Action Programme. Official journal of the European Communities, No C 328/1.

FEAP, (1993). Fifth Environmental Action Programme. Official journal of the European Communities, No C 138/5.

IEEP, (2010). The Institute for European Environmental Policy. Strategic Orientations of EU Environmental Policy under the Sixth Environment Action Programme and Implications for the Future Final Report.

İKV, (2014). Avrupa 2020 Stratejisi. İktisadi Kalkınma Vakfı Yayınları Yayın No: 269.

Kıvılcım, İ. (2014). AB'de 7 'nci Çevre Eylem Programı Başladı, İktisadi Kalkınma Vakfı İKV Değerlendirme Notu 82.

OBYKP, (2013). Onuncu Beş Yıllık Kalkınma Planı. [Çevrim-içi: http://www.kalkinma.gov.tr/Pages/KalkinmaPlanlari.aspx], Erişim Tarihi: 24.11.2016.

Özgüler, V. C. (2013). Avrupa Birliği ve Türkiye İşgücü Piyasalarının Karşılaştırmalı Analizi, 1.Basım. İstanbul: Cinius Yayınları.

SBYKP, (2001). Sekizinci Beş Yıllık Kalkınma Planı. [Çevrim-içi: http://www.kalkinma.gov.tr/Pages/KalkinmaPlanlari.aspx], Erişim Tarihi: 01.11.2016.

Scheuer, S. (2005). EU Environmental Policy Handbook .A Critical Analysis of EU Environmental Legislation. European Environmental Bureau (EEB). 
(1986).

Single

European

Act.

[Available

online

at:

http://www.consilium.europa.eu/uedocs/cmsUpload/SingleEuropeanAct_Crest.pdf], Retrieved on June 17,2016.

SEAP, (2002). Sixth Environmental Action Programme. Official Journal of the European Communities, No L 242/1.

SEAP, (2013). Seventh Environmental Action Programme. Official Journal of the European Communities, No L $354 / 171$.

Sencar, P. (2007). Türkiye'de Çevre Koruma Ve Ekonomik Büyüme Ilişsisi. Yüksek Lisans Tezi Edirne Trakya Üniversitesi Sosyal Bilimler Enstitüsü.

Şeren, G. Y., ve Dedebek, E. (2013). AB Uyum Sürecinde Türkiye'de Çevre Politikalar1. In EY International Congress on Economics I (EYC2013), (No. 265). Ekonomik Yaklasim Association, Ankara, Turkey.

TA, (1997). The Treaty of Amsterdam. [Available online at: http://europa.eu/eu-law/decisionmaking/treaties/pdf/treaty_of_amsterdam/treaty_of_amsterdam_en.pdf], Retrieved on June 30,2016.

$\begin{array}{lllllll}\text { TBMM, (2011). Türkiye Büyük Millet Meclisi } 1982 & \text { Anayasast. [Çevrim-içi: }\end{array}$ https://yenianayasa.tbmm.gov.tr/docs/gerekceli_1982_anayasasi.pdf], Erişim Tarihi: 12.07.2016.

TEAP, (1983). Third Environmental Action Programme. Official Journal of the European Communities, Volume 26 C 46.

TEU, (1992). The Treaty on European Union. [Available online at: http://europa.eu/eu-law/decisionmaking/treaties/pdf/treaty_on_european_union/treaty_on_european_union_en.pdf], Retrieved on June 22,2016.

Toprak, D. (2006). Sürdürülebilir Kalkınma Çerçevesinde Çevre Politikaları Ve Mali Araçlar. Süleyman Demirel Üniversitesi Sosyal Bilimler Enstitüsü Dergisi,2:4,146-169.

TUSIAD, (1998). Türk Sanayici ve Işsadamları Derneği Dış Ticarette Çevre Koruma Kaynaklı Tarife Dışı Teknik Engeller Ve Türk Sanayi için Eylem Planı. İstanbul: Lebib Yalkın Yayımları ve Basım İşleri A.Ş.

Ungureanu, C.I. \& Marcu, M. (2006). The Lisbon Strategy. Journal for economic forecasting, 3:1,74-83.

ÜBYKP, (1973). Üçüncü Beş Yllık Kalkınma Planı. http://www.kalkinma.gov.tr/Pages/KalkinmaPlanlari.aspx], Erişim Tarihi: 08.07.2016.

YBYKP, (1996). Yedinci Beş Yllık Kalkınma Planı. [Çevrim-içi: http://www.kalkinma.gov.tr/Pages/KalkinmaPlanlari.aspx], Erişim Tarihi: 23.10.2016.

Yıldırım, U. ve Budak, S. (2010). AB tam üyelik sürecinde Türkiye'nin çevre politikasındaki değişimler. Mustafa Kemal Üniversitesi Sosyal Bilimler Enstitüsü Dergisi. 7:13,173-191.

Yıldız, N. (2005). Türkiye'nin Avrupa Birliği’ne Uyum Sürecinde Çevre Politikalarının Karşılaştırmalı Analizi. Trakya Üniversitesi Sosyal Bilimler Dergisi. 6:1, 164-173. 